Global and regional controls on marine redox changes across the Ordovician-Silurian

\title{
boundary in South China
}

\author{
Yu Liu ${ }^{\text {a,b,c }}$, Chao Li ${ }^{\text {c* }}$, Thomas J. Algeo ${ }^{\text {c,d,e }}$, Junxuan Fan $^{\text {f }}$, Ping'an Peng ${ }^{\text {a }}$
}

${ }^{a}$ State Key Laboratory of Organic Geochemistry, Guangzhou Institute of Geochemistry of CAS, Guangzhou 510640, China

${ }^{\mathrm{b}}$ University of Chinese Academy of Sciences, Beijing 100049, China

${ }^{\mathrm{c}}$ State Key Laboratory of Biogeology and Environmental Geology, China University of Geosciences, Wuhan 430074, China

${ }^{\mathrm{d}}$ State Key Laboratory of Geological Processes and Mineral Resources, China University of Geosciences, Wuhan 430074, China

${ }^{\mathrm{e}}$ Department of Geology, University of Cincinnati, Cincinnati, OH 45221, U.S.A.

${ }^{\mathrm{f}}$ State Key Laboratory of Palaeobiology and Stratigraphy, Nanjing Institute of Geology and Palaeontology, Chinese Academy of Sciences, Nanjing 210008, China

*Corresponding author. Tel: +86-27-67883606; Email address: chaoli@cug.edu.cn

\section{Abstract}

The Ordovician-Silurian (O-S) transition coincided with significant environmental and biological changes. In South China, the Yangtze Platform experienced both global and 
regional events at this time, including sea-level fluctuations, tectonic movements, volcanic eruptions, mass extinction, and widespread anoxia. The O-S transitional strata of the Yangtze Platform comprise organic-rich black shales that are an important oil source rock. To explore the evolution of watermass chemistry and its relationship to organic matter accumulation, we conducted an integrated Fe-S-C geochemical study (i.e., Fe-speciation, $\delta^{13} \mathrm{C}_{\mathrm{org}}, \delta^{34} \mathrm{~S}_{\mathrm{py}}$, pyrite-S and TOC) of the O-S boundary sections at Datianba (Chongqing Municipality) and Shuanghe (Sichuan Province). These sections were located in the restricted inner Yangtze Sea, in contrast to the previously studied Wangjiawan section, which was deposited in a more open setting of the outer Yangtze Sea. In contrast to the well-oxygenated conditions at Wangjiawan, the Datianba and Shuanghe sections record persistently anoxic, and episodically euxinic, conditions during the Hirnantian, which can be explained by the unique paleogeography and restricted hydrography of the inner Yangtze Sea. We propose that the regional Kwangsian Orogeny, which was driven by collision of the Yangtze and Cathaysia blocks, played a key role in basin development, watermass chemistry changes, and accumulation of Wufeng Formation black shales within the Yangtze Sea. The more widespread black shales of the Lower Silurian Lungmachi Formation were linked to the post-Hirnantian global marine transgression.

Keywords: Yangtze Platform; Kwangsian Orogeny; Hirnantian glaciation; Fe speciation; black shale; anoxia 


\section{Introduction}

The Late Ordovician (Katian-Hirnantian) to Early Silurian (Rhuddanian) ( 453-441 Ma, referred to herein as the 'O-S transition') was an important interval in Earth history, during which a series of events of global consequence took place. These events included the Hirnantian glaciation and deglaciation, one of the 'Big Five' mass extinctions and a post-extinction faunal recovery, large sea-level changes, and the widespread deposition of organic-rich shales (see review in Algeo et al., 2016). The relationships among these events are still not fully understood. For example, some authors have proposed that the biological extinction was caused directly by cooling associated with the Hirnantian glaciation (Stanley, 2010; McGhee et al., 2012), whereas others have linked it to glacially induced changes in oceanic redox conditions (e.g., Harper et al., 2013). The latter hypothesis involves two different views of ocean-redox changes during the Hirnantian glaciation: (1) increasingly oxic conditions (e.g., Sheehan, 1988; Melchin and Mitchell, 1991; Skelton, 1994; Brenchley et al., 2001; Yan et al., 2012), or (2) increasingly reducing conditions (e.g., Zhang et al., 2009; Hammarlund et al., 2012).

The causes of widespread deposition of black shales in the aftermath of the Hirnantian glaciation are under debate also (Lüning, 2005; Armstrong et al., 2006; Le Heron et al., 2009; Loydell et al., 2009). One theory contends that glaciation enhanced physical weathering on the continents, generating rock flour with a high surface-to-volume ratio (Saltzman, 2005). Intensified chemical weathering during the subsequent deglaciation then released large amounts of nutrients such as phosphorus, silica and ferrous iron that were transported to the 
ocean, leading to algal blooms. Generally high primary productivity and organic carbon sinking fluxes led to the development of black shales. However, in South China, black shale formation began much earlier than elsewhere, during the Katian (i.e., pre-glaciation), and continued for longer, into the Telychian (mid-Silurian) (Chen et al., 2004; Yan et al., 2012; Gorjan et al., 2012).

The protracted deposition of black shales on the South China Craton may have been due to unusual paleogeographic boundary conditions (Chen et al., 2004; Melchin et al., 2013). During the Early Paleozoic, South China was largely isolated from other continents (Fig. 1A). This craton consisted of the Yangtze and Cathaysia blocks, which were separated by the Neoproterozoic-early Paleozoic Nanhua Basin and welded together during the OrdovicianSilurian Kwangsian Orogeny (Chen et al., 2014). The Yangtze Platform, which comprised the central part of the Yangtze Block, was surrounded by emergent uplifts on three sides and connected to the open ocean to the north (note: all orientations given are modern compass directions), generating the mostly enclosed epeiric Yangtze Sea (Fig. 1B). Owing to this distinct paleogeographic pattern, the Yangtze Sea exhibited weak to no watermass restriction in its outer regions (to the north-northeast) and strong watermass restriction in its inner regions (to the south-southwest). Owing to its relative restriction, regional tectonic events strongly influenced the evolution of water redox conditions in the inner Yangtze Sea during the Late Ordovician to Early Silurian.

The O-S transition interval in South China was marked by major regional volcanic and tectonic events, including frequent volcanic eruptions (Su et al., 2003, 2007, 2009) and the Kwangsian Orogeny (Chen et al., 2012, 2014). The composition of K-bentonites in the O-S 
black shale succession indicates a source related to subduction-zone volcanism, possibly associated with convergence of the Cathaysia and Yangtze blocks (Su et al., 2003, 2006). The Kwangsian Orogeny, first proposed by Ting (1929), was a major tectonic event that produced an angular unconformity between O-S strata and overlying Devonian strata in South China. However, the influence of these two important regional events on the evolution of environmental and watermass redox conditions in the Yangtze Sea are not well understood.

In order to explore the combined effects of global and regional events on the evolution of watermass redox conditions and the accumulation of organic-rich shales during the O-S transition, we measured Fe-speciation, isotopic data $\left(\delta^{13} \mathrm{C}_{\mathrm{org}}\right.$ and $\left.\delta^{34} \mathrm{~S}_{\mathrm{py}}\right)$, and elemental abundance data (TOC and pyrite-S) in samples from the Datianba and Shuanghe sections (Fig. 1D). Using the data from these restricted-marine sections of the Yangtze Platform in combination with previously published data from the more open marine Wangjiawan section, we aim to reconstruct the marine redox evolution of the Yangtze Sea and evaluate controls on black shale accumulation during the Late Ordovician to Early Silurian. We emphasize that the results of our analysis pertain strictly to the Yangtze Sea, and that the oceanographic conditions that prevailed there (particularly in its highly restricted inner regions) were probably not representative of contemporaneous global open-ocean conditions.

\section{Geologic setting}

Although the Kwangsian Orogeny peaked in intensity in the late Silurian, episodic deformation affected the South China Craton during the O-S transition interval (Chen et al., 2014). Based on an analysis of lithostratigraphic and biofacies patterns from the Pearl River 
Basin and Jiangnan Slope Belt, Chen et al. (2012) inferred Kwangsian tectonic activity during the Sandbian ( 458-453 Ma) to late Katian ( 453-445 Ma; note: all absolute ages are from the timescale of Gradstein et al., 2012). Among other effects, orogenic uplift to the southeast caused development of a foreland basin with a depocenter that migrated northwestward during the Late Ordovician (Chen et al., 2014). Continued uplift later produced a regional unconformity between Silurian and overlying Devonian strata of the Yangtze Platform (Chen et al., 2013).

The two sections analyzed in this study are the Datianba section (Xiushan County, Chongqing Municipality) and the Shuanghe section (Changning County, Sichuan Province) (Fig. 1B), which were located in the strongly restricted inner Yangtze Sea, to the north of the Central Guizhou Oldland (Fig. 1B). The approximate average water depths of these sections prior to the Hirnantian glacio-eustatic regression were $150( \pm 50) \mathrm{m}$ based on the assemblage of benthic invertebrates, especially brachiopods (Zeng, 1991). We compared the two study sections with the Wangjiawan section (Zigui County, Hubei Province), which was located in an open-marine setting of the outer Yangtze Sea at similar or slightly deeper water depths ( 200( $(100)$ m; He et al., 2002). The Wangjiawan section has been intensively studied with regard to its biostratigraphy (Chen et al., 2000a; Vandenbroucke et al., 2005), paleogeography (Zhang et al., 2000; Chen et al., 2004), and chemostratigraphy (Chen et al., 2005; Fan et al., 2009). The stratigraphic succession of the O-S transition interval is similar in all three sections, comprising the Wufeng Formation, Kuanyinchiao Bed, and Lungmachi Formation (Fig. 1C). The Wufeng and Lungmachi formations consist of organic-rich black shales containing abundant graptolite fossils. The Kuanyinchiao Bed is dominantly 
composed of carbonaceous limestones which contain abundant shelly fossils, recording a drop in eustatic elevations (Fan et al., 2009, Fig.1D). The associated Hirnantian Fauna is recognized as a cool/cold water fauna (Rong et al., 2002), possibly related to global cooling during the Hirnantian glacial episode ( 445-444 Ma). Biostratigraphic control in the study sections is provided by graptolites, for which regional and global zonation schemes for the Ordovician-Silurian are well-established (Chen et al., 2000a, b; Su et al., 2003; Cooper and Sadler, 2012; see summary in Zhou et al., 2015).

\section{Iron speciation as a paleoredox proxy}

In order to evaluate local watermass conditions, we measured the concentrations of total $\mathrm{Fe}\left(\mathrm{Fe}_{\mathrm{T}}\right)$ and the highly reactive $\mathrm{Fe}\left(\mathrm{Fe}_{\mathrm{HR}}\right)$ pool, including $\mathrm{Fe}$ in pyrite $\left(\mathrm{Fe}_{\mathrm{py}}\right)$, carbonate $\left(\mathrm{Fe}_{\mathrm{carb}}\right)$, oxide $\left(\mathrm{Fe}_{\mathrm{ox}}\right)$, and magnetite $\left(\mathrm{Fe}_{\mathrm{mag}}\right)$ in shales from the Datianba and Shuanghe sections. These proxies have been proven to be effective in distinguishing among oxic-suboxic, ferruginous, and euxinic conditions in paleomarine systems (Raiswell and Canfield, 1998; Lyons and Severmann, 2006; Li et al., 2010). Studies of ancient and modern sediments deposited beneath anoxic bottom waters show that $\mathrm{Fe}_{\mathrm{HR}} / \mathrm{Fe}_{\mathrm{T}}$ usually exceeds 0.38 (Poulton and Raiswell, 2002; Raiswell and Canfield, 1998). Furthermore, the ratio of the $\mathrm{Fe}_{\mathrm{py}} / \mathrm{Fe}_{\mathrm{HR}}$ can be used to distinguish euxinic water columns (anoxic and $\mathrm{H}_{2} \mathrm{~S}$-bearing) from ferruginous water columns (anoxic and $\mathrm{Fe}^{2+}$-bearing). Empirically, $\mathrm{Fe}_{\mathrm{py}} / \mathrm{Fe}_{\mathrm{HR}}$ exceeds 0.7-0.8 under euxinic conditions because the reactive Fe phases are effectively titrated out of the system before appreciable $\mathrm{H}_{2} \mathrm{~S}$ starts to accumulate in the water column ( $\mathrm{Li}$ et al., 
2015a). A recent study showed that, in order to ensure that the results of iron speciation analysis are valid, $\mathrm{Fe}_{\mathrm{T}}$ should be $>0.5 \%$ (Clarkson et al., 2014) (note: all concentrations are given as weight percent).

\section{Samples and methods}

\subsection{Samples}

A total of 104 outcrop samples were collected from the Datianba (61 samples) and the Shuanghe (43 samples) sections, ranging from the upper Katian to the lower Rhuddanian. All samples were pulverized to powders of $>200$ mesh after removing potential weathering surfaces and veins. Visible pyrite nodules or beds were also discarded before powdering in order to minimize the influence of late diagenetic processes on bulk-rock chemistry.

All Fe-S-C geochemical analyses were conducted in the State Key Laboratory of Biogeology and Environmental Geology, China University of Geosciences (Wuhan). A detailed description of these routine methods can be found in Li et al. (2015a, 2015b), with a brief summary given below.

\subsection{Fe speciation analysis}

Disseminated pyrites in samples were extracted using the Cr-reduction method (Canfield et al., 1986). Pyrite sulfur was collected in silver nitrate traps, and the resulting $\operatorname{Ag}_{2} \mathrm{~S}$ 
precipitates were dried and weighed. The pyrite content and the amount of $\mathrm{Fe}_{\mathrm{py}}$ were then calculated stoichiometrically. One or two pure pyrite standards (Alfa Aesar) were extracted for each batch, yielding a mean recovery of $95.4 \pm 2.5 \%(1 \sigma, \mathrm{n}=7)$. The amounts of $\mathrm{Fe}_{\text {carb}}$, $\mathrm{Fe}_{\mathrm{ox}}$ and $\mathrm{Fe}_{\text {mag }}$ were measured using the sequential extraction procedure described in Poulton and Canfield (2005), with quantification by Atomic Absorption Spectroscopy (AAS). Due to the present lack of internationally certificated standards for sequential extraction of $\mathrm{Fe}$ species, we used two shale standards (CUG-2, CUG-3) that have been repeatedly tested in the Lyons biogeochemistry laboratory at the University of California-Riverside (UCR) as a control during sequential Fe extractions (Li et al., 2015b).

The concentrations of total iron $\left(\mathrm{Fe}_{\mathrm{T}}\right)$ were measured using a portable X-ray fluorescence spectrometer (Olympus DS6000). Chinese National Reference Material GBW07107 (i.e., GSR-5, a shale standard, n = 3) and GBW07108 (i.e., GSR-6, a muddy dolostone standard, $\mathrm{n}=3$ ) were used for replicate analyses; each yielded an analytical error better than $\pm 0.6 \%$.

\subsection{Sulfur isotopic analysis}

The $\mathrm{Ag}_{2} \mathrm{~S}$ precipitates from the pyrite extractions were combusted with excess $\mathrm{V}_{2} \mathrm{O}_{5}$ and analyzed using a Thermo Scientific Delta V Plus isotope ratio mass spectrometer coupled with a Flash elemental analyzer to determine sulfur isotopic composition of pyrite $\left(\delta^{34} S_{\mathrm{py}}\right)$. S-isotopic values are reported as per mille (\%) deviation relative to the VCDT (Vienna Cañon Diablo Troilite) international standard. An analytical precision of $\pm 0.2 \%$ ( $1 \sigma)$ was 
calculated from replicate analyses of IAEA international standards IAEA-S1 $(-0.3 \%)$, IAEA-S2 (+22.65\%), and IAEA-S3 (-32.5\%).

\subsection{Total organic carbon and carbon isotope analysis}

Total organic carbon (TOC) was determined using an elemental analyzer (LECO CS 230) after treating $\sim 0.1 \mathrm{~g}$ powdered samples with $6-\mathrm{M} \mathrm{HCl}$ at $80{ }^{\circ} \mathrm{C}$ for $4 \mathrm{~h}$ to remove carbonate. Isotopic determinations for organic carbon were carried out on an elemental analyzer combined with a Thermo DELTA plus XL mass spectrometer. Kerogen was isolated from $~ 3$ $\mathrm{g}$ of rock powder using conventional $\mathrm{HCl}-\mathrm{HF}$ digestion methods and then combusted at $1000{ }^{\circ} \mathrm{C}$ to determine its $\mathrm{C}$-isotopic composition $\left(\delta^{13} \mathrm{C}_{\mathrm{org}}\right)$. Two replicate measurements were made per sample. C-isotopic values were calibrated against the Chinese standard GBW04408 $(-36.91 \%)$ and expressed as per mille (\%o) deviation relative to VPDB (Vienna Pee Dee Belemnite). Six replicate analyses of GBW04408 yielded an analytical precision better than $\pm 0.1 \%$ o $(1 \sigma)$.

\section{Results}

Fe-S-C geochemical data acquired in this study are summarized in Table 1 and illustrated in Figs. 2, 3 and 4.

\subsection{Fe speciation}


At Datianba, $\mathrm{Fe}_{\mathrm{T}}$ ranges from 1.3 to $3.4 \%$ with a mean of $2.2 \%$ (Fig. 2). $\mathrm{Fe}_{\mathrm{T}}$ increases upsection within the Katian, reaching a maximum (3.4\%) in the uppermost Katian before declining sharply to $1.0 \%$ in the middle Hirnantian (Kuanyinchiao Bed). After that, $\mathrm{Fe}_{\mathrm{T}}$ increases to $2.6 \%$ and remains nearly constant through the Rhuddanian. $\mathrm{Fe}_{\mathrm{HR}} / \mathrm{Fe}_{\mathrm{T}}$ ranges from 0.45 to 1.00 with a mean of $0.70 . \mathrm{Fe}_{\mathrm{HR}} / \mathrm{Fe}_{\mathrm{T}}$ is higher in the lower-middle Hirnantian than in the Katian or Rhuddanian. $\mathrm{Fe}_{\mathrm{py}} / \mathrm{Fe}_{\mathrm{HR}}$ ranges from 0.41 to 0.90 (mean 0.72 ) and shows a generally upward-increasing trend, exceeding 0.70 in the upper Katian. After sustained high values in the lower Hirnantian, $\mathrm{Fe}_{\mathrm{py}} / \mathrm{Fe}_{\mathrm{HR}}$ decreases steadily and reaches a minimum in the middle Hirnantian. In the Rhuddanian, $\mathrm{Fe}_{\mathrm{py}} / \mathrm{Fe}_{\mathrm{HR}}$ values stabilize around 0.7.

At Shuanghe, $\mathrm{Fe}_{\mathrm{T}}$ ranges from 0.7 to $3.0 \%$ with a mean of $1.5 \%$ (Fig. 3). Higher $\mathrm{Fe}_{\mathrm{T}}$ values are observed in the uppermost Katian and lower-middle Hirnantian. $\mathrm{Fe}_{\mathrm{HR}} / \mathrm{Fe}_{\mathrm{T}}$ ranges from 0.69 to 1.00 (mean 0.83 ), with no systematic trends through the section. $\mathrm{Fe}_{\mathrm{py}} / \mathrm{Fe}_{\mathrm{HR}}$ ranges from 0.43 to 0.84 with a mean of 0.66 . $\mathrm{Fe}_{\mathrm{py}} / \mathrm{Fe}_{\mathrm{HR}}$ increases gradually through the upper Katian and reaches peak values in the lower-middle Hirnantian before decreasing in the upper Hirnantian.

Iron speciation data for the Wangjiawan (North) section were reported by Yan et al. (2012) (Fig. 4B). $\mathrm{Fe}_{\mathrm{HR}} / \mathrm{Fe}_{\mathrm{T}}$ ranges from 0.10 to 0.66 with a mean of 0.36. In general, $\mathrm{Fe}_{\mathrm{HR}} / \mathrm{Fe}_{\mathrm{T}}$ values are higher (>0.38) in the Katian and Rhuddanian (except for one sample at $1.85 \mathrm{~m}$ with a $\mathrm{Fe}_{\mathrm{HR}} / \mathrm{Fe}_{\mathrm{T}}$ of 0.29$)$ and lower in the lower-middle Hirnantian $(<0.38) . \mathrm{Fe}_{\mathrm{py}} / \mathrm{Fe}_{\mathrm{HR}}$ varies between 0.19 and 0.74 with a mean of 0.58 , showing relative higher values $(>0.60)$ in the lower-middle Hirnantian. 


\subsection{TOC and organic carbon isotopes}

The TOC contents of upper Katian samples at Datianba range from 2.2 to $8.9 \%$ (mean $4.3 \%$ ) and show an upward-increasing trend (Fig. 2). TOC decreases gradually through the lower-middle Hirnantian, reaching a minimum $(0.4 \%)$ in the Kuanyinchiao Bed, and then returns to pre-excursion levels within the Lungmachi Formation. $\delta^{13} \mathrm{C}_{\text {org }}$ ranges between $-31.1 \%$ and $-30.2 \%$ through much of the Katian, followed by a positive excursion commencing at the uppermost Katian and peaking at $-27.6 \%$ in the early Hirnantian. $\delta^{13} \mathrm{C}_{\text {org }}$ values then decrease rapidly through the middle Hirnantian and remain relatively stable around $-30.5 \%$ through the Rhuddanian.

At Shuanghe, TOC contents vary between 1.2 and $9.7 \%$ with a mean of $4.4 \%$ (Fig. 3). TOC values are relatively high through the upper Katian and the early Hirnantian but reach a minimum in the middle Hirnantian. In late Hirnantian and Rhuddanian, TOC increases gradually and reaches a peak in the lower part of this interval. $\delta^{13} \mathrm{C}_{\mathrm{org}}$ values are relatively stable ( $-30.8 \%$ to $-30.4 \%$ ) within the lower to middle part of Katian, followed by a positive excursion to a peak of $-29.0 \%$ in the early Hirnantian. This is followed by a decline to relatively stable $\delta^{13} \mathrm{C}_{\text {org }}$ values of $-30.3 \%$ through the late Hirnantian and Rhuddanian.

At Wangjiawan (Riverside) (Fig. 4A), TOC contents range from 0.2 to $8.3 \%$ with a mean of $4.4 \%$. TOC increases in the upper Katian and then begin to decrease in the early Hirnantian, reaching a minimum in the Kuanyinchiao Bed. TOC contents increased again during deposition of the Lungmachi Formation. A published $\delta^{13} \mathrm{C}_{\text {org }}$ profile for the 
Wangjiawan Riverside section (Chen et al., 2005; Fan et al., 2009; Fig. 4A) shows variation between $-30.5 \%$ and $-28.5 \%$, including a positive excursion that starts in the uppermost Katian and reaches a peak in the middle Hirnantian before declining to about $-30.4 \%$ through the upper Hirnantian and Rhuddanian.

\subsection{Pyrite content and sulfur isotopes}

At Datianba, pyrite concentrations range from 1.0 to $6.0 \%$, with a mean of $2.3 \%$ (Fig. 2). High values are observed in the upper Katian and Rhuddanian and low values in the middle Hirnantian. $\delta^{34} \mathrm{~S}_{\mathrm{py}}$ values vary between $-26.4 \%$ and $+6.1 \%$ in the Katian, showing an upward-increasing trend. $\delta^{34} \mathrm{~S}_{\mathrm{py}}$ values peak in the M. extraordinarius Zone and decline through the Kuanyinchiao and into the lowermost Lungmachi Formation, thereafter remaining relatively stable (around $-5 \%$ ) within the Rhuddanian.

At Shuanghe, pyrite concentrations range from 0.4 to $3.6 \%$, with a mean of $1.8 \%$ (Fig. 3). Pyrite concentrations are relatively stable through most of the Katian, increase abruptly in the uppermost Katian, and remain at relatively high values $(\sim 2.5 \%)$ in the lower Hirnantian. In the middle Hirnantian, pyrite concentrations decrease gradually, stabilizing at $\sim 1 \%$ through the Rhuddanian. $\delta^{34} \mathrm{~S}_{\mathrm{py}}$ shows large fluctuations within the Katian (from $-16.8 \%$ o to $+13.0 \%$ ) superimposed on an overall upward-increasing trend. Maximum $\delta^{34} \mathrm{~S}_{\mathrm{py}}$ values are observed in the lower-middle Hirnantian, followed by slightly lower $\delta^{34} \mathrm{~S}_{\mathrm{py}}$ values within the Rhuddanian.

Pyrite concentration and $\delta^{34} S_{\text {py }}$ data for the Wangjiawan (Riverside) section were 
reported by Gorjan et al. (2012) (Fig. 4A). Their results show no obvious changes in pyrite concentrations through the section, with most values around $1 \%$ with the exception of peaks in the upper Katian and the lower Hirnantian. $\delta^{34} S_{\text {py }}$ values vary between $-20 \%$ and $-10 \%$ in Katian and lower part of the lower Hirnantian. This is followed by large fluctuations in the upper part of the lower Hirnantian and maximum $\delta^{34} \mathrm{~S}_{\mathrm{py}}$ values in the middle Hirnantian. In the upper Hirnantian, $\delta^{34} S_{\text {py }}$ values return to the pre-excursion baseline of ca. $-20 \%$, although large variations are recorded in the Rhuddanian.

\section{Discussion}

\subsection{Paleo-redox conditions in Yangtze Sea}

At Datianba, all samples contain $>0.5 \% \mathrm{Fe}_{\mathrm{T}}$, indicating that redox interpretations based on iron speciation data are potentially robust (cf. Clarkson et al., 2014). All samples have $\mathrm{Fe}_{\mathrm{HR}} / \mathrm{Fe}_{\mathrm{T}}$ values of $>0.38$, indicating deposition under anoxic bottom waters, but substantial variation in $\mathrm{Fe}_{\mathrm{py}} / \mathrm{Fe}_{\mathrm{HR}}$ (Fig. 2) implies fluctuations between euxinic and ferruginous conditions during different stages. The upper Katian is characterized by $\mathrm{Fe}_{\mathrm{py}} / \mathrm{Fe}_{\mathrm{HR}}>0.7$, suggesting euxinic conditions. Within the lower-middle Hirnantian, $\mathrm{Fe}_{\mathrm{py}} / \mathrm{Fe}_{\mathrm{HR}}$ shifts from higher values in the M. extraordinarius Zone (range 0.70-0.90, mean 0.81) to lower values in the Kuanyinchiao Bed (range 0.41-0.79, mean 0.58), indicating a transition from mainly euxinic to mainly ferruginous conditions. The upper Hirnantian and lower Rhuddanian are characterized by $\mathrm{Fe}_{\mathrm{py}} / \mathrm{Fe}_{\mathrm{HR}}>0.7$, indicating a return to dominantly euxinic conditions. 
The redox pattern at Shuanghe is broadly similar to that at Datianba although with some differences in detail. All samples from Shuanghe have $\mathrm{Fe}_{\mathrm{T}}>0.5 \%$ and $\mathrm{Fe}_{\mathrm{HR}} / \mathrm{Fe}_{\mathrm{T}}>0.38$, indicating anoxic bottom waters. Most Katian samples yield $\mathrm{Fe}_{\mathrm{py}} / \mathrm{Fe}_{\mathrm{HR}}<0.7$, indicating dominantly ferruginous conditions, although three samples near the top of the Katian yield $\mathrm{Fe}_{\mathrm{py}} / \mathrm{Fe}_{\mathrm{HR}}>0.7$, suggesting episodes of euxinia. $\mathrm{Fe}_{\mathrm{py}} / \mathrm{Fe}_{\mathrm{HR}}$ remains $>0.7$ within the lower-middle Hirnantian, including in the Kuanyinchiao Bed, indicating dominantly euxinic conditions throughout the glacial interval. In the Rhuddanian, $\mathrm{Fe}_{\mathrm{py}} / \mathrm{Fe}_{\mathrm{HR}}$ is $<0.7$, indicating dominantly ferruginous conditions.

Redox conditions in the Wangjiawan (North) section were investigated by Yan et al. (2012) on the basis of iron speciation data (Fig. 4B). In their study, $\mathrm{Fe}_{\mathrm{HR}}$ is the sum of $\mathrm{Fe}_{\mathrm{ox}}$ and $\mathrm{Fe}_{\mathrm{py}}$, which is generally lower than the sum of $\mathrm{Fe}_{\mathrm{carb}}, \mathrm{Fe}_{\mathrm{ox}}, \mathrm{Fe}_{\mathrm{mag}}$ and $\mathrm{Fe}_{\mathrm{py}}$, i.e., the definition of $\mathrm{Fe}_{\mathrm{HR}}$ in the present study. They used 0.8 as the threshold value of $\mathrm{Fe}_{\mathrm{py}} / \mathrm{Fe}_{\mathrm{HR}}$ for distinguishing ferruginous from euxinic conditions, which is higher than our threshold of 0.7-0.8 (taken from Poulton and Canfield, 2011). Most samples in the Katian and the upper Hirnantian-Rhuddanian yield $\mathrm{Fe}_{\mathrm{HR}} / \mathrm{Fe}_{\mathrm{T}}>0.38$ and $\mathrm{Fe}_{\mathrm{py}} / \mathrm{Fe}_{\mathrm{HR}}<0.8$, indicating dominantly anoxic-ferruginous conditions. In the lower-middle Hirnantian, $\mathrm{Fe}_{\mathrm{HR}} / \mathrm{Fe}_{\mathrm{T}}$ is $<0.38$, indicating oxic-suboxic bottom waters. In the latter interval, high $\mathrm{Fe}_{\mathrm{py}} / \mathrm{Fe}_{\mathrm{HR}}$ values were attributed by Yan et al. (2012) to diagenetic and epigenetic sulfidation.

Based on the Fe speciation data discussed above, we conclude that the evolution of watermass redox conditions in the two study sections located in the inner Yangtze Sea (Datianba and Shuanghe) was more complicated than that at Wangjiawan, which was located in an open-marine setting. During the late Katian, Datianba was characterized by euxinia and 
Shuanghe by transient euxinia, whereas Wangjiawan had a ferruginous watermass. The most obvious differences occurred in the early to middle Hirnantian, at the time of the glacio-eustatic lowstand, when Wangjiawan experienced oxic conditions but the water columns at Datianba and Shuanghe remained anoxic, with a transition from euxinic to ferruginous conditions at the former and persistent euxinia at the latter. These observations imply that the water columns at Datianba and Shuanghe in the inner Yangtze Sea region remained stratified even during the interval of maximum glacio-eustatic regression. During the late Hirnantian and Rhuddanian, watermass redox conditions similar to those of the late Katian were re-established in each of the three sections. The different patterns of redox changes among these sites imply a strong spatial heterogeneity of oceanic redox chemistry during the O-S transition that can be related to paleogeographic controls (see Section 6.3).

\subsection{Carbon and sulfur cycling through $O-S$ transition}

The early to middle Hirnantian shows evidence of major changes in carbon cycling in the Yangtze Sea (Figs. 2-4). For all three sections, TOC contents are highest in the Wufeng and Lungmachi formations, and a positive $\delta^{13} \mathrm{C}_{\mathrm{org}}$ excursion commences in the upper Katian and peaks in the Hirnantian. The observed changes are broadly consistent with previously published records from coeval sections around the world, implying global controls (Fan et al., 2009; Yan et al., 2009; Zhang et al., 2009, 2010; Gorjan et al., 2012; Hammarlund et al., 2012).

Drawing on redox interpretations based on iron speciation data (see Section 6.1), it is 
possible to infer controls on carbon cycling during the O-S transition. At all three sections, bottom waters were anoxic during the Katian and late Hirnantian-Rhuddanian, facilitating the accumulation of organic matter. In contrast, oxic conditions prevailed at Wangjiawan in the early to middle Hirnantian, limiting the buildup of organic matter. Better oxygenated conditions were established through either shallowing of the Wangjiawan section into the surface layer of the Yangtze Sea during the Hirnantian glacio-eustatic regression, or improved ventilation of its thermocline region as a result of glacially invigorated oceanic overturning circulation (cf. Wilde, 1987; Zhang et al., 2009). On the other hand, bottom-water conditions remained anoxic at Datianba and Shuanghe during the Hirnantian glacial interval, so the decline in TOC seen in these sections must reflect a different mechanism, e.g., reduced primary productivity caused by low inputs of weathered nutrients during the glaciation.

The causes of the positive $\delta^{13} \mathrm{C}_{\text {org }}$ excursion in the Hirnantian are still in dispute. A weathering mechanism, based on intense erosion of carbonate platforms that were exposed during the glacio-eustatic lowstand as a source of abundant ${ }^{13} \mathrm{C}$-enriched carbonate to the ocean (Kump et al., 1999; Melchin and Holmden, 2006), has been invoked to explain the positive $\delta^{13} \mathrm{C}_{\text {org }}$ excursion observed at Wangjiawan (Fan et al., 2009). This mechanism is supported by the synchronous positive $\delta^{13} \mathrm{C}_{\text {carb }}$ excursions that have been reported from numerous sections around the world (Finney et al., 1999; Melchin and Holmden, 2006; Yan et al., 2009; Cramer et al., 2011). An alternative mechanism is based on enhanced burial of organic matter (Marshall et al., 1997; Brenchley et al., 2003; Saltzman and Young, 2005; Gill et al., 2011; Zhou et al., 2015). We favor the latter mechanism as an explanation for the positive $\delta^{13} \mathrm{C}_{\text {org }}$ excursion in the two study sections owing to strong covariation among TOC, 
$\delta^{13} \mathrm{C}_{\text {org }}$, and $\delta^{34} \mathrm{~S}_{\mathrm{py}}$. Zhou et al. (2015) reported that the Hirnantian positive $\delta^{13} \mathrm{C}_{\text {org }}$ excursion was regionally diachronous due to spatial variations in marine productivity and organic matter burial. Such diachroneity is an indication that the Wangjiawan $\delta^{13} \mathrm{C}_{\text {org }}$ record responded to both global (e.g., seawater $\delta^{13} \mathrm{C}_{\text {DIC }}$ ) and regional influences (e.g., marine productivity).

A major perturbation of the marine sulfur cycle during the Hirnantian is indicated by covariation of pyrite and TOC content and by increasing $\delta^{34} S_{p y}$, which correlates with increasing $\delta^{13} \mathrm{C}_{\text {org }}$ (Figs. 2-3). These patterns can be produced by either local or basin-wide processes. In the local mechanism, a $\delta^{34} S_{\text {py }}$ positive excursion can be produced by movement of the $\mathrm{O}_{2}-\mathrm{H}_{2} \mathrm{~S}$ chemocline from the water column into the sediment, resulting in microbial sulfate reduction (MSR) under more sulfate-limited conditions. This mechanism, which was proposed by Yan et al. (2009) for the Wangjiawan section, is consistent with the shift from anoxic to oxic conditions inferred from iron speciation data (see Section 6.1). However, it does not take into account the observed increases in TOC, $\delta^{13} \mathrm{C}_{\mathrm{org}}$, and pyrite content before the Hirnantian, all of which favor a basin-wide mechanism related to increased organic matter accumulation rates. As a result of an enhanced organic carbon burial flux, intensified MSR may have led to burial of larger quantities of ${ }^{32} \mathrm{~S}$-enriched sedimentary sulfide, resulting in ${ }^{34} \mathrm{~S}$-enriched sulfate in the water column and, in the longer term, a positive excursion of $\delta^{34} S_{\text {py }}$ (Habicht et al., 1997).

6.3. Controls on redox changes and carbon-sulfur cycling in Yangtze Sea during O-S transition 
The study sections were located in restricted-marine settings of the Yangtze Sea during the O-S transition. Major lithofacies changes in each section document the influence of large glacio-eustatic fluctuations associated with the Hirnantian glaciation, but strong spatial redox heterogeneity among the study sections suggests that there must have been local influences on the redox evolution of the Yangtze Sea as well. Here, we propose a dual-control mechanism involving both Hirnantian glacio-eustasy and regional tectonic effects of the Kwangsian Orogeny (Fan et al., 2011; Chen et al., 2014).

\subsubsection{Hirnantian glacio-eustasy}

The Hirnantian glaciation resulted in a maximum glacio-eustatic regression of $\sim 70-100$ m (Brenchley et al., 2003; Finnegan et al., 2011). The global sea-level fluctuations caused by growth and decay of Hirnantian icesheets are considered to have been an important influence on contemporaneous marine redox conditions (Lüning et al., 2000; Landing, 2011), although the exact nature of these effects has been debated. In most shallow-marine sections globally (i.e., shelf settings at water depths $<200 \mathrm{~m}$ ), the onset of the Hirnantian glaciation was marked by enhanced oxygenation and its termination by a shift toward more reducing conditions (Yan et al., 2012; Zhang et al., 2011; Zhou et al., 2012). In general, this pattern reflects shallowing of sections within the ocean-surface layer during the peak of the glaciation, and deepening into the upper thermocline region during the subsequent deglaciation. On the other hand, sea-level movements had little direct effect on redox conditions in the deep-ocean environment (>200 m water depth), where changes in the rate of overturning circulation, upwelling intensity, and organic matter sinking fluxes were probably 
more important factors. The Hirnantian glaciation has been proposed to have caused both expanded anoxia (Zhang et al., 2009; Hammarlund et al., 2012) and improved oxygenation (Chen et al., 2004; Yan et al., 2012) in the deep-ocean environment.

In this study, only the Wangjiawan section shows a pattern of secular redox variation (Section 6.1) consistent with dominantly glacio-eustatic controls. As global sea levels fell in the early Hirnantian, bottom waters at Wangjiawan evolved gradually from anoxic to oxic conditions, and at the end of the glaciation, global sea-level rise led to re-establishment of anoxic conditions. In contrast, the large Hirnantian glacio-eustatic fluctuations had limited effects on watermass redox conditions at Datianba and Shuanghe. The Hirnantian sea-level cycle resulted in a shift from euxinic to ferruginous and back to euxinic conditions at Datianba, whereas euxinic conditions persisted throughout the glacial interval at Shuanghe. The different redox patterns in these two sections argue against a basinwide hydrographic mechanism, e.g., increasing restriction and reduced seawater sulfate concentrations in the inner Yangtze Sea, because such processes would have affected both sections equally. A more plausible control is differences in depositional water depths, with a slightly shallower setting at Datianba resulting in its movement into the suboxic (i.e., ferruginous) upper thermocline region during the Hirnantian lowstand, and a deeper setting at Shuanghe resulting in its maintenance of euxinic conditions. A redox switch to euxinic conditions at Datianba and to ferruginous conditions at Shuanghe during the late Hirnantian and Rhuddanian may be attributed to a rise in the oceanic chemocline (i.e., $\mathrm{O}_{2}-\mathrm{H}_{2} \mathrm{~S}$ interface) associated with the post-Hirnantian eustatic transgression (Fig. 5E). However, local water depths at the two study sections were controlled not only by glacio-eustasy but also by regional tectonic influences. 


\subsubsection{Kwangsian Orogeny}

The Kwangsian Orogeny, which began in the Late Ordovician owing to convergence of the Cathaysia and Yangtze blocks (Chen et al., 2012, 2014), exerted a strong influence on sedimentation patterns and watermass redox conditions across the Yangtze Platform. Tectonic uplift began in the southeast, adjacent to the Cathaysia Block, and migrated northwestward toward the southeastern margin of the Yangtze Platform during the late Katian. As this deformation progressed, the Yangtze Platform gradually evolved into an enclosed and semi-restricted marine basin (Chen et al., 2014), creating boundary conditions that favored deep water anoxia, as shown by Fe speciation data (see Section 6.1). These conditions, amplified by glacio-sea-level drop, generally facilitated the accumulation of organic matter and led to positive $\mathrm{C}$ and $\mathrm{S}$ isotopic excursions during the Hirnantian (see Section 6.2).

Spatial migration of tectonic deformation related to the Kwangsian Orogeny resulted in diachronous redox changes within the Yangtze Sea. Euxinic conditions developed first during the late Katian at the Datianba section (Fig. 2), probably owing to its proximity to the weathering sources in the Cathaysia Block (Fig. 1B; Chen et al., 2004), which provided increasing weathering nutrient input (Yan et al., 2010) and result in the formation of productivity-driven anoxic water condition. Such a water condition facilitates the MSR, thus further promoted euxinic developments in the eastern portion of the inner Yangtze Sea (Fig. 5A, B). At that time, redox conditions in the Shuanghe section remained dominantly ferruginous owing to its location in the innermost Yangtze Sea, further from the area of initial 
tectonic subsidence. As Kwangsian deformation proceeded, the deepest part of the Yangtze Sea shifted northwestward, resulting in the onset of euxinic conditions in the Shuanghe section during the early Hirnantian (Fig. 5C). The Wangjiawan section, which was located much further to the east (paleo-north), exhibited persistently ferruginous watermass conditions during the late Katian owing to a minimum of influence from the Kwangsian Orogeny and to its good connection with the open ocean, which prevented buildup of $\mathrm{H}_{2} \mathrm{~S}$ produced by MSR.

During the early Hirnantian, the two study sections in the inner Yangtze Sea (Datianba and Shuanghe) continued to exhibit euxinic watermass conditions despite the onset of the Hirnantian glacio-eustatic regression (Brenchley et al., 2003; Finnegan et al., 2011). We attribute this relationship to restriction of the deep watermass of the inner Yangtze Sea as a result of subsidence caused by Kwangsian tectonism and of glacio-sea-level drop (Fig. 5C). The Datianba section eventually developed ferruginous deepwater conditions during deposition of the Kuanyinchiao Bed, coinciding with the peak of the Hirnantian regression and possibly influenced by continued shifting of the Yangtze Sea depocenter northwestward as Kwangsian tectonism progressed (Fig. 5D). This redox change reflects a shoaling of the Datianba section into the chemocline, suggesting that a stratified water column persisted even as sea level fell sharply. At Shuanghe, deep waters remained euxinic throughout the entire glacial interval, possibly as a result of Kwangsian-related subsidence counteracting the effects of the Hirnantian regression (Fig. 5C, D). This inference is supported by evidence of increasing watermass restriction at Shuanghe during the Hirnantian glacial interval.

In summary, redox conditions in the Datianba and Shuanghe sections were likely 
controlled by a combination of Hirnantian glacio-eustasy and bathymetric changes within the Yangtze Sea related to the Kwangsian Orogeny. Orogenic-related tectonism during the Late Ordovician resulted specifically in (1) uplift of the margins of the Yangtze Platform and increasing nutrient input from southeast old lands and increasing watermass restriction of the inner Yangtze Sea in its interior, and (2) a rolling southeast-to-northwest pattern of subsidence within the Yangtze Sea that influenced local water depths, at times canceling out the effects associated with contemporaneous glacio-eustatic fluctuations (Fig. 5A-E). In contrast, the Wangjiawan section, which was located in the unrestricted outer Yangtze Sea, was only minimally influenced by the Kwangsian Orogeny and records primarily the effects of Hirnantian glacio-eustasy.

\subsection{Implications for organic accumulation in O-S black shales on Yangtze Platform}

Much research has shown a direct link between marine anoxia and the deposition of black shales (e.g., Arthur and Sageman, 1994; Negri et al., 2009; Jenkyns, 2010). The connections linking them include organic carbon fluxes (Meyer and Kump, 2008), sea level changes (Landing, 2011), nutrient cycling (Algeo and Scheckler, 1998; Saltzman, 2005; Slomp and Van Cappellen, 2007; Tsandev et al., 2008), and paleogeographic factors (Trabucho-Alexandre et al., 2012). Anoxia greatly enhances the preservation of organic matter by reducing microbiological decay (Canfield, 1994; Tyson, 2005). Water-column anoxia is commonly associated with high primary productivity since large quantities of sinking organic matter can reduce dissolved oxygen levels to zero (Pedersen and Calvert, 1990; Zhang et al., 2005). Rapid sedimentation also favors preservation of organic matter, 
limiting its decay in the water column and allowing significant buildup in relatively shallow-water systems (Keil et al., 1994; Hartnett et al., 1998). A broad consensus has emerged that productivity and preservation factors generally operate in tandem to produce organic-rich deposits (Tyson, 2005).

Deposition of black shale on the Yangtze Platform commenced with the Katian Wufeng Formation. These shales were deposited synchronously across the Yangtze Sea in response to increasing deepwater restriction linked to Kwangsian tectonism (Chen et al., 2014) in combination with increases in marine productivity triggered by terrigenous nutrient inputs (See Section 6.3; Chen et al., 2011; Yan et al., 2012). Moreover, high marine productivity can be driven by volcanically sourced nutrients (Dawson, 2000; Su et al., 2003; Jones et al., 2008; Olgun et al., 2013), and the Wufeng Formation contains abundant volcanic ash beds (Su et al., 2009). These beds record plinian eruptive events from a syn-collisional volcanic arc on the southeastern margin of the Yangtze Platform (related to convergence of the Yangtze and Cathaysia Blocks) based on analysis of K-bentonite compositions ( $\mathrm{Su}$ et al., 2006, 2009). We infer that high productivity during deposition of the Wufeng Formation was probably due to a combination of nutrients delivered by volcanic ash and riverine inputs related to enhanced subaerial weathering (See Section 6.3; Chen et al., 2011).

Most black shale deposition during the O-S transition was associated with the post-glacial eustatic transgression of the late Hirnantian to early Rhuddanian, an interval characterized by high sea-level elevations and warm, sluggish ocean circulation (Armstrong and Coe, 1997; Chen et al., 2004; see Section 6.3.1). On the Yangtze Platform, black shales of the late Hirnantian-Rhuddanian Lungmachi Formation formed primarily due to these 
factors. Additionally, recent paleogeographic studies have shown that the timing of onset and termination of black shale deposition in the Lungmachi Formation gradually shifted from southeast to northwest across the Yangtze Sea (Su et al., 2009; Fan et al., 2011). This diachroneity was probably linked to tectonic movements of the Kwangsian Orogeny, in which basin subsidence shifted northwest owing to compressive deformation between the Cathaysia and Yangtze blocks, with crustal loading of the latter by the former (Fig. 5).

\section{Conclusions}

Analysis of Fe-C-S system data for two sections (Datianba and Shuanghe) from the restricted inner Yangtze Sea, and comparison with similar published datasets for the Wangjiawan section from the unrestricted outer Yangtze Sea, provided new insights regarding the evolution of marine redox conditions and controls on organic matter accumulation during the Ordovician-Silurian $(\mathrm{O}-\mathrm{S})$ transition. First, these sections document significant spatial heterogeneity in bottom-water redox conditions. The Datianba and Shuanghe sections remained anoxic throughout the O-S transition, whereas the Wangjiawan section exhibited a shift to oxic conditions during the Hirnantian glacial period. At Datianba, bottom waters were euxinic during the late Katian and late Hirnantian-Rhuddanian but shifted to a ferruginous condition during deposition of the Kuanyingchiao Bed in the early to middle Hirnantian. An almost opposite redox pattern occurred at Shuanghe, where the late Katian and late Hirnantian-Rhuddanian were characterized by ferruginous conditions and the early-middle Hirnantian by euxinic conditions. At Wangjiawan, bottom waters were ferruginous during the 
Katian and late Hirnantian-Rhuddanian.

We propose that spatial heterogeneity of watermass redox conditions on the Yangtze Platform was controlled by a combination of Hirnantian glacio-eustasy and tectonic movements linked to the regional Kwangsian Orogeny. Positive covariation of $\delta^{13} \mathrm{C}_{\text {org }}$ and $\delta^{34} \mathrm{~S}_{\mathrm{py}}$ at the inner-platform Datianba and Shuanghe sections indicates that co-burial of organic matter and pyrite were key influences on positive $\mathrm{C}$ and $\mathrm{S}$ isotope excursions during the Hirnantian, reflecting a global increase in primary productivity and MSR. The different organic matter distribution patterns at Datianba and Shuanghe document the influence of localized subsidence of the Yangtze Platform due to the Kwangsian Orogeny. Organic matter accumulation peaked in the Katian Wufeng Formation at Datianba but in the late Hirnantian-Rhuddanian Lungmachi Formation at Shuanghe, reflecting secular migration of the basin depocenter from southeast to northwest owing to compressional deformation of the Yangtze Platform by Kwangsian tectonism. Black shale deposition at Wangjiawan was similar before and after the Hirnantian glaciation, suggesting organic matter accumulation was controlled principally by glacio-eustasy and that the Kwangsian Orogeny had little influence on outer-platform sections. Our study highlights the influence of regional geologic events on the evolution of watermass redox conditions in the South China Yangtze Sea during the O-S transition as well as demonstrating the need to comparatively analyze regional and global patterns in order to understand environmental controls during major geologic events.

\section{Acknowledgments}


We thank Qing Chen and Zhongyang Chen for their helps in field and Zihu Zhang and Chengsheng Jin for their assistance on experimental aspect respectively. This study was supported by the Chinese 973 program (grant No. 2013CB955704), the NSFC (grant No. 41172030) to CL. PP acknowledges support from the NSFC (grant NO. 41321002). TJA acknowledges support from the U.S. National Science Foundation Sedimentary Geology and Paleobiology Program (EAR-1053449), the NASA Exobiology Program (NNX13AJ1IG), and the China University of Geosciences, Wuhan (SKL-GPMR program GPMR201301, and SKL-BGEG program BGL201407).

\section{References}

Algeo, T.J., Scheckler, S.E., 1998. Terrestrial-marine teleconnections in the Devonian: links between the evolution of land plants, weathering processes, and marine anoxic events. Philosophical Transactions of the Royal Society of London B: Biological Sciences 353, 113-130.

Algeo, T.J., Marenco, P.J., Saltzman, M.R., 2016. Co-evolution of oceans, climate, and the biosphere during the 'Ordovician Revolution': A review. Palaeogeogr. Palaeoclimatol. Palaeoecol. 458, 1-11.

Armstrong, H.A., Coe, A.L., 1997. Deep-sea sediments record the geophysiology of the Late Ordovician glaciation. J. Geol. Soc. London. 154, 929-934.

Armstrong, H.A., Turner, B.R., Makhlouf, I.M., Weedon, G.P., Williams, M., Al Smadi, A., Abu Salah, A., 2006. Reply to "Origin, sequence stratigraphy and depositional 
environment of an Upper Ordovician (Hirnantian) deglacial black shale, Jordan”. Palaeogeogr. Palaeoclimatol. Palaeoecol. 230, 356-360.

Arthur, M.A., Sageman, B.B., 1994. Marine black shales: Depositional mechanisms and environments of ancient deposits. Ann. Rev. Earth Planet. Sci. 22, 499-551.

Brenchley, P.J., Marshall, J.D., Underwood, C.J., 2001. Do all mass extinctions represent an ecological crisis? Evidence from the Late Ordovician. Geol. J. 36, 329-340.

Brenchley, P.J., Carden, G.A.F., Hints, L., Kaljo, D., Marshall, J.D., Martma, T., Meidla, T., Nolvak, J., 2003. High-resolution stable isotope stratigraphy of Upper Ordovician sequences: constraints on the timing of bioevents and environmental changes associated with mass extinction and glaciation. Geol. Soc. Am. Bull. 115, 89-104.

Canfield, D.E., 1994. Factors influencing organic carbon preservation in marine sediments. Chem. Geol. 114, 315-329.

Canfield, D.E., Raiswell, R., Westrich, J.T., Reaves, C.M., Berner, R.A., 1986. The use of chromium reduction in the analysis of reduced inorganic sulfur in sediments and shales. Chem. Geol. 54, 49-155.

Chen, X., Rong, J.Y., Mitchell, C.E., Harper, D.A.T., Fan, J.X., Zhan, R.B., Zhang, Y.D., Li, R.Y., Wang, Y., 2000a. Late Ordovician to earliest Silurian graptolite and brachiopod biozonation from the Yangtze region, South China, with a global correlation. Geol. Mag. $137,623-650$.

Chen, D.Z., Wang, J.G., Yan, D.T., Wei, H.Y., Y, H., Wang, Q.C., 2011. Environmental dynamics of organic accumulation for the principal Paleozoic source rocks on Yangtze 
block. Chin. J. Geol. 46, 5-26 (in Chinese).

Chen, X., Rong, J.Y., Fan, J.X., Zhan, R.B., Zhang, Y.D., Li, R.Y., Wang, Y., Mitchell, C.E., Harper, D.A.T., 2000b. A global correlation of zones across the Ordovician-Silurian boundary. Acta Palaeontol. Sin. 39, 100-114.

Chen, X., Rong, J.Y., Li, Y., Boucot, A.J., 2004. Facies patterns and geography of the Yangtze region, South China, through the Ordovician and Silurian transition. Palaeogeogr. Palaeoclimatol. Palaeoecol. 204, 353-372.

Chen, X., Melchin, M.J., Sheets, H.D., 2005. Patterns and processes of latest Ordovician graptolite extinction and recovery based on data from South China. J. Paleontol. 79, $842-861$.

Chen, X., Rong, J.Y., Fan, J.X., Zhan, R.B., Mitchell, C.E., Harper, D.A.T., Melchin, M.J., Peng, P.A., Finney, S.C., Wang, X.F., 2006. The Global Boundary Stratotype Section and Point (GSSP) for the base of the Hirnantian Stage (the uppermost of the Ordovician System). Episodes 29, 183-196.

Chen, X., Zhang, Y.D., Fan, J.X., Tang, L., Sun, H.Q., 2012. Onset of the Kwangsian Orogeny as evidenced by biofacies and lithofacies. Sci. China D (Earth Sci.) 55, 1592-1600.

Chen, X., Bergstrom, S.M., Zhang, Y.D., Wang, Z.H., 2013. A regional tectonic event of Katian (Late Ordovician) age across three major blocks of China. Chin. Sci. Bull. 58, 4292-4299.

Chen, X., Fan, J.X., Chen, Q., Tang, L., Hou, X.D., 2014. Toward a stepwise Kwangsian 
Orogeny. Sci. China D (Earth Sci.) 57, 379-387.

Clarkson, M.O., Poulton, S.W., Guilbaud, R., Wood, R.A., 2014. Assessing the utility of $\mathrm{Fe} / \mathrm{Al}$ and Fe-speciation to record water column redox conditions in carbonate-rich sediments. Chem. Geol. 382, 111-122.

Cooper, R.A., Sadler, P.M., 2012. The Ordovician Period, in: Gradstein, F.M., Ogg, J.G., Schimtz, M.D., Ogg, G.M. (Eds.), The Geologic Time Scale 2012. Elsevier, Amsterdam, pp. $489-523$.

Cramer, B.D., Brett, C.E., Melchin, M.J., Männik, P., Kleff ner, M.A., McLaughlin, P.I., Loydell, D.K., Munnecke, A., Jeppsson, L., Corradini, C., Brunton, F.R., Saltzman, M.R., 2011. Revised correlation of Silurian Provincial Series of North America with global and regional chronostratigraphic units and $\delta^{13} \mathrm{C}_{\text {carb }}$ chemostratigraphy. Lethaia 44, 185-202.

Dawson, W.C., 2000. Abstract: Shale microfacies: Eagle Ford Group (Cenomanian-Turonian) north-central Texas outcrops and subsurface equivalents. AAPG Bull. 80, 607-621.

Fan, J.X., Peng, P.A., Melchin, M.J., 2009. Carbon isotopes and event stratigraphy near the Ordovician-Silurian boundary, Yichang, South China. Palaeogeogr. Palaeoclimatol. Palaeoecol. 276, 160-169.

Fan, J.X., Melchin, M.J., Chen, X., Wang, Y., Zhang, Y.D., Chen, Q., Chi, Z.L., Chen, F., 2011. Biostratigraphy and geography of the Ordovician-Silurian Longmaxi black shales in South China. Sci. China D (Earth Sci.) 54, 1854-1863.

Finnegan, S., Bergmann, K., Eiler, J.M., Jones, D.S., Fike, D.A., Eisenman, I., Hughes, N.C., Tripati, A.K., Fischer, W.W., 2011. The magnitude and duration of Late 
Ordovician-Early Silurian glaciation. Science 331, 903-906.

Finney, S.C., Berry, W.B.N., Cooper, J.D., Ripperdan, R.L., Sweet, W.C., Jacobsen, S.R., Soufiane, A., Achab, A., Noble, P.J., 1999. Late Ordovician mass extinction: a new perspective from stratigraphic sections in central Nevada. Geology 27, 215-218.

Gill, B.C., Lyons, T.W., Young, S.A., Kump, L.R., Knoll, A.H., Saltzman, M.R., 2011. Geochemical evidence for widespread euxinia in the Later Cambrian ocean. Nature 469, 80-83.

Gorjan, P., Kaiho, K., Fike, D.A., Chen, X., 2012. Carbon- and sulfur-isotope geochemistry of the Hirnantian (Late Ordovician) Wangjiawan (Riverside) section, South China: Global correlation and environmental event interpretation. Palaeogeogr. Palaeoclimatol. Palaeoecol. 337, 14-22.

Gradstein, F.M., Ogg, J.G., Schmitz, M., Ogg, G. (Eds.), 2012. The Geologic Time Scale 2012, 2 vols., Elsevier, Amsterdam.

Habicht, K.S., Canfield, D.E., 1997. Sulfur isotope fractionation during bacterial sulfate reduction in organic-rich sediments. Geochim. Cosmochim. Acta 61, 5351-5361.

Hammarlund, E.U., Dahl, T.W., Harper, D.A.T., Bond, D.P.G., Nielsen, A.T., Bjerrum, C.J., Schovsbo, N.H., Schönlaub, H.P., Zalasiewicz, J.A., Canfield, D.E., 2012. A sulfidic driver for the end-Ordovician mass extinction. Earth. Planet. Sci. Lett. 331, 128-139.

Harper, D.A.T., Hammarlund, E.U., Rasmussen, C.M.Ø., 2014. End Ordovician extinctions: A coincidence of causes. Gondwana. Res. 25, 1294-1307.

Hartnett, H.E., Richard, G.K., Hedges, J.I., Devol, A.H., 1998. Influence of oxygen exposure 
time on organic carbon preservation in continental marine regions. Nature. 391, 572-575.

He, W.H., Wang, X.F., Bu, J.J., 2002. The eustatic cycles and the depth of water mass of the latest Ordovician Wufengian in the Yangtze basin. Acta. Sedimentol. Sin. 20, 367-375 (in Chinese).

Jenkyns, H.C., 2010. Geochemistry of oceanic anoxic events. Geochem. Geophys. Geosyst. 11, 1-30.

Jones, M.T., Gislason, S.R., 2008. Rapid releases of metal salts and nutrients following the deposition of volcanic ash into aqueous environment. Geochim. Cosmochim. Acta. 72, 3361-3680.

Keil, G.R., Montlucon, D.B., Prahl, F.G., Hedges, J.I., 1994. Sorptive preservation of labile organic matter in marine sediments. Nature. 370, 549-552.

Kump, L.R., Arthur, M.A., 1999. Interpreting carbon isotope excursions: Carbonates and organic matter. Chem. Geol. 161, 181-198.

Landing, E., 2011. Time-specific black mudstones and global hyperwarming on the Cambrian-Ordovician slope and shelf of the Laurentia palaeocontinent. Palaeogeogr. Palaeoclimatol. Palaeoecol. 367, 256-272.

Le Heron, D.P., Craig, J., Etienne, J.L., 2009. Ancient glaciations and hydrocarbon accumulations in North Africa and the Middle East. Earth Sci. Rev. 93, 47-76.

Li, C., Love, G.D., Lyons, T.W., Sessions, A.L., Fike, D.A., Chu, X., 2010. A stratified redox model for the Ediacaran ocean. Science 328, 80-83. 
Li, C., Planavsky, N.J., Love, G.D., Reinhard, C.T., Hardisty, D., Feng, L.J., Bates, S.M., Huang, J., Zhang, Q., Chu, X.L., Lyons, T.W., 2015a. Marine redox conditions in the middle Proterozoic ocean and isotopic constraints on authigenic carbonate formation: Insights from the Chuanlinggou Formation, Yanshan Basin, North China. Geochim. Cosmochim. Acta 150, 90-105.

Li, C., Planavsky, N.J., Shi, W., Zhang, Z.H., Zhou, C.M., Cheng, M., Tarhan, L.G., Luo, G.M., Xie, S.C., 2015b. Ediacaran marine redox heterogeneity and early animal ecosystems. Sci. Rep. 5, 1-8.

Loydell, D.K., Butcher, A., Fryda, J., Lüning, S., Fowler, M., 2009. Lower Silurian "hot shales" in Jordan: A new depositional model. J. Pet. Geol. 32, 261-270.

Lüning, S., Craig, J., Loydell, D.K., Štorch, P., Fitches, B., 2000. Lower Silurian "hot shales” in North Africa and Arabia: Regional distribution and depositional mode. Earth. Sci. Rev. 49, 121-200.

Lüning, S., Shahin, Y.M., Loydell, D., Al-Rabi, H.T., Masri, A., Tarawneh, B., Kolonic, S., 2005. Anatomy of a world-class source rock: Distribution and depositional model of Silurian organic-rich shales in Jordan and implications for hydrocarbon potential. AAPG Bull. 89, 1397-1427.

Lyons, T.W., Severmann, S., 2006. A critical look at iron paleoredox proxies based on new insights from modern euxinic marine basins. Geochim. Cosmochim. Acta 70, 5698-5722.

Marshall, J.D., Brenchley, P.J., Mason, P., Wolff, G.A., Astini, R.A., Hints, L., Meidla, T., 1997. Global carbon isotopic events associated with mass extinction and glaciation in the 
late Ordovician. Palaeogeogr. Palaeoclimatol. Palaeoecol. 132, 195-210.

McGhee, G.R., Sheehan, P.M., Bottjer, D.J., Droser, M.L., 2012. Ecological ranking of Phanerozoic biodiversity crises: The Serpukhovian (early Carboniferous) crisis had a greater ecological impact than the end-Ordovician. Geology 40, 147-150.

Melchin, M.J., Holmden, C., 2006. Carbon isotope chemostratigraphy in Arctic Canada: sea-level forcing of carbonate platform weathering and implications for Hirnantian global correlation. Palaeogeogr. Palaeoclimatol. Palaeoecol. 234, 186-200.

Melchin, M.J., Mitchell, C.E., 1991. Late Ordovician extinction in the Graptoloidea, in: Barnes, C.R., Williams, S.H. (Eds.), Advances in Ordovician Geology. Geol. Surv. Canada Pap. 90(9), pp. 59-78.

Melchin, M.J., Mitchell, C.E., Holmden, C., Štorch, P., 2013. Environmental changes in the Late Ordovician-early Silurian: Review and new insights from black shales and nitrogen isotopes. Geol. Soc. Am. Bull. 125, 1635-1670.

Meyer, K.M., Kump, L.R., 2008. Oceanic euxinia in Earth history: Causes and consequences. Ann. Rev. Earth Planet. Sci. 36, 251-288.

Negri, A., Ferretti, A., Wagner, T., Meyers, P.A., 2009. Phanerozoic organic-carbon-rich marine sediments: Overview and future research challenges. Palaeogeogr. Palaeoclimatol. Palaeoecol. 273, 218-227.

Olgun, N., Duggen, S., Andronico, D., Kutterolf, S., Croot, P.L., Giammanco, S., Censi, P., Randazzo, L., 2013. Possible impacts of volcanic ash emissions of Mount Etna on the primary productivity in the oligotrophic Mediterranean Sea: Results from nutrient-release 
experiments in seawater. Mar. Chem. 152, 32-42.

Pedersen, T.F., Calvert, S.E., 1990. Anoxic vs. productivity: what controls the formation of organic-carbon-rich sediments and sedimentary rocks? Am. Assoc. Pet. Geol. Bull. 74, 454-466.

Poulton, S.W., Canfield, D.E., 2005. Development of a sequential extraction procedure for iron: implications for iron partitioning in continentally derived particulates. Chem. Geol. 214, 209-221.

Poulton, S.W., Canfield, D.E., 2011. Ferruginous conditions: a dominant feature of the ocean through Earth's history. Elements 7(2), 107-112.

Poulton, S.W., Raiswell, R., 2002. The low-temperature geochemical cycle of iron: from continental fluxes to marine sediment deposition. Am. J. Sci. 302, 774-805.

Raiswell, R., Canfield, D.E., 1998. Sources of iron for pyrite formation in marine sediments. Am. J. Sci. 298, 219-245.

Rong, J.Y., Chen, X., Harper, D.A.T., 2002. The latest Ordovician Hirnantian Fauna (Brachiopoda) in time and space. Lethaia 35, 213-249.

Saltzman, M.R., 2005. Phosphorus, nitrogen, and the redox evolution of the Paleozoic oceans. Geology 33, 573-576.

Saltzman, M.R., Young, S.A., 2005. Long-lived glaciation in the Late Ordovician? Isotopic and sequence-stratigraphic evidence from western Laurentia. Geology 33(2), 109-112.

Sheehan, P.M., 1988. Late Ordovician events and the terminal Ordovician extinction. 
New Mexico Bur. Min. Mineral. Resourc. Mem. 44, 405-415.

Skelton, P.W., 1994. Radiations and extinctions in the history of life: what turns the "wheel of fortune"? Eur. Palaeontol. Newsl. 6, 15-21.

Slomp, C.P., Van Cappellen, P., 2007. The global marine phosphorus cycle: Sensitivity to oceanic circulation. Biogeosciences 4, 155-171.

Stanley, S.M., 2010. Thermal barriers and the fate of perched faunas. Geology 38, 31-34.

Su, W.B., He, L.Q., Wang, Y.B., Gong, S.Y., Zhou, H.Y., 2003. K-bentonite beds and high-resolution integrated stratigraphy of the uppermost Ordovician Wufeng and the lowest Silurian Longmaxi formations in South China. Sci. China D (Earth Sci.) 46, $1121-1133$.

Su, W.B., Li, Z.M., Shi, X.Y., 2006. K-bentonites and black/dark shales from the Wufeng-Longmaxi Fm. (Early Paleozoic, South China) and Xiamaling Fm. (Early Neoproterozoic, North China): Implications for tectonic processes during two important transitions. Earth. Sci. Front. 13, 82-95.

Su, W.B., Li, Z.M., Ettensohn, F.R., Johnson, M.E., Huff, W.D., Wang, W., Ma, C., 2007. Tectonic and eustatic control on the distribution of black-shale source beds in the Wufeng and Longmaxi Formations (Ordovician-Silurian), South China. Front. Earth Sci. China 1, 470-481.

Su, W.B., Huff, W.D., Ettensohn, F.R., Liu, X.M., Zhang, J.E., Li, Z.M., 2009. K-bentonite, black-shale and flysch successions at the Ordovician-Silurian transition, South China: Possible sedimentary responses to the accretion of Cathaysia to the Yangtze block and its 
implications for the evolution of Gondwana. Gondwana Res. 15, 111-130.

Ting, V.K., 1929. The orogenic movements in China (presidential address of the 6th Annual Meeting). Bull. Geol. Soc. China. 8, 151-170.

Trabucho-Alexandre, J., Hay, W.W., de Boer, P.L., 2012. Phanerozoic environments of black shale deposition and the Wilson cycle. Solid Earth 3, 29-42.

Tsandev, I., Slomp, C.P., Van Cappellen, P., 2008. Glacial-interglacial variations in marine phosphorus cycling: Implications for ocean productivity. Glob. Biogeochem. Cycles 22, 962-966.

Tyson, R.V., 2005. The "productivity versus preservation" controversy; cause, flaws, and resolution. In: Harris, N.B. (Ed.). Deposition of Organic-Carbon-Rich Sediments: Models, Mechanisms, and Consequences: Society for Sedimentary Geology (SEPM-SSG) Special Publication 82, PP. 17-33.

Vandenbroucke, T.R.A., Chen, X., Verniers, J., 2005. A study on the preliminary results of latest Ordovician chitinozoan from Wangjiawan, Yichang, China. Acta Palaeontol. Sin. 44, 203-208.

Wilde, P., 1987. Model of progressive ventilation of the late Precambrian-early Paleozoic ocean. Am. J. Sci. 287, 442-459.

Yan, D.T., Chen, D.Z., Wang, Q.C., Wang, J.G., Wang, Z.Z., 2009. Carbon and sulfur isotopic anomalies across the Ordovician-Silurian boundary on the Yangtze platform, South China. Palaeogeogr. Palaeoclimatol. Palaeoecol. 274, 32-39.

Yan, D.T., Chen, D.Z., Wang, Q.C., Wang, J.G., 2010. Large-scale climatic fluctuations in the 
latest Ordovician on the Yangtze block, south China. Geology 38, 599-602.

Yan, D.T., Chen, D.Z., Wang, Q.C., Wang, J.G., 2012. Predominance of stratified anoxic Yangtze Sea interrupted by short-term oxygenation during the Ordo-Silurian transition. Chem. Geol. 291, 69-78.

Zeng, Q.L., 1991. Ordovician brachiopod communities and eustatic changes of sea level in the eastern Yangtze Gorges area. Bull. Yichang Inst. Geol. Mineral Resources Chinese Acad. Geol. Sci. 16, 13-39 (in Chinese).

Zhang, S.C., Zhang, B.M., Bian, L.Z., 2005. Development constraints of marine source rock in China. Geosci. Front. 12, 39-48 (in Chinese with English abstract).

Zhang, T.G., Shen, Y.N., Zhan, R.B., Shen, S.Z., Chen, X., 2009. Large perturbations of the carbon and sulfur cycle associated with the Late Ordovician mass extinction in South China. Geology 37, 299-302.

Zhang, T.G., Shen, Y., Algeo, T.J., 2010. High-resolution carbon isotopic records from south China: implications for atmospheric $\mathrm{CO}_{2}$ changes during the Ordovician. Palaeogeogr. Palaeoclimatol. Palaeoecol. 289, 102-112.

Zhang, T.G., Trela, W., Jiang, S.Y., Nielsen, J.K., Shen, Y.A., 2011. Major oceanic redox condition change correlated with the rebound of marine animal diversity during the Late Ordovician. Geology 39, 675-678.

Zhang, T.S., Kershaw, S., Wan, Y., Lan, G.Z., 2000. Geochemical and facies evidence for palaeoenvironmental change during the Late Ordovician Hirnantian glaciation in South Sichuan Province, China. Glob. Planet. Change 24, 133-152. 
Zhou, L., Wignall, P.B., Su, J., Feng, Q.L., Xie, S.C., Zhao, L.S., Huang, J.H., 2012. U/Mo ratios and $\delta^{98} \mathrm{Mo}$ as local and global redox proxies during mass extinction events. Chem. Geol. 324-325, 97-107.

Zhou, L., Algeo, T.J., Shen, J., Hu, Z.F., Gong, H.M., Xie, S.C., Huang, J.H., Gao, S., 2015. Changes in marine productivity and redox conditions during the Late Ordovician Hirnantian glaciation. Palaeogeogr. Palaeoclimatol. Palaeoecol. 420, 223-234.

\section{Figure Captions}

Figure 1. Geological background. (A) Late Ordovician global paleogeography (modified from Melchin et al., 2013). (B) Paleogeographic map of the Yangtze Platform during the Late Ordovician (modified from Chen et al., 2004). Note that the Yangtze Platform was rotated $\sim 90^{\circ}$ counter-clockwise relative to its modern orientation. (C) General stratigraphy of the Upper Ordovician to Lower Silurian in South China. The red lines a-a' and b-b' represent the transects shown in Figure 5. (D) Photographs of Datianba (left) and Shuanghe (right) sections.

Figure 2. Geochemistry of the Datianba section. The red bars next to the stratigraphic column represent layers of volcanic ash. The horizontal blue line represents the possible boundary between the Ordovician and the Silurian, which has not been identified to date. Asterisks represent mass extinction events. Hirn: Hirnantian; Ky: Kuanyinchiao; extra: extraordinarius; HF: Hirnantian Fauna. Graptolite zonation according to Chen et al. (2000a, b) 
and Su et al. (2003).

Figure 3. Geochemistry of the Shuanghe section. Other details as in Figure 2.

Figure 4. Geochemistry of the Wangjiawan sections. (A) Riverside Section; (B) North Section. Stratigraphy and graptolite zonation are based on Chen et al. (2006). Published $\delta^{13} \mathrm{C}_{\text {org }}$ data from Chen et al. (2006) and Fan et al. (2009). Sulfide concentrations and $\delta^{34} \mathrm{~S}_{\mathrm{py}}$ data from Gorjan et al. (2012). Fe speciation data from Yan et al. (2012). Other details as in Figure 2.

Figure 5. Water redox condition evolution along the transect a-a' (right to left) and transect b-b' (left to right) in Figure 1B during early stage of the late Katian (A), late stage of the late Katian (B), early Hirnantian (C), middle Hirnantian (D) and late Hirnantian and Rhuddanian (E). The nutrient input and oceanic productivity were estimated based on tectonic rising and the development of Hirnantian glaciation. 
Table 1. Fe-S-C data derived from Datianba and Shuanghe sections

\begin{tabular}{|c|c|c|c|c|c|c|c|c|c|c|c|c|}
\hline Samples & $\begin{array}{c}\text { Height } \\
\text { (m) }\end{array}$ & Formation & Lithology & $\begin{array}{l}\text { TOC } \\
(\%)\end{array}$ & $\begin{array}{c}\text { Pyrite } \\
(\%)\end{array}$ & $\begin{array}{l}\mathrm{Fe}_{\mathrm{T}} \\
(\%)\end{array}$ & $\mathrm{Fe}_{\mathrm{HR}} / \mathrm{Fe}_{\mathrm{T}}$ & $\mathrm{Fe}_{\mathrm{P}} / \mathrm{Fe}_{\mathrm{HR}}$ & $\mathrm{Fe}_{\mathrm{ox}} / \mathrm{Fe}_{\mathrm{T}}$ & $\mathrm{Fe}_{\mathrm{carb}} / \mathrm{Fe}_{\mathrm{T}}$ & $\delta^{13} \mathrm{C}_{\text {org }}$ & $\delta^{34} S_{p y}$ \\
\hline \multicolumn{13}{|c|}{ Datianba Section } \\
\hline $\mathrm{L} 40$ & 17.60 & Lungmachi & Black Shale & 1.41 & 1.72 & 2.3 & 0.45 & 0.77 & 0.012 & 0.082 & -30.1 & -7.3 \\
\hline L39 & 16.99 & Lungmachi & Black Shale & 1.82 & 1.77 & 2.6 & 0.46 & 0.69 & 0.026 & 0.102 & -30.4 & -7.7 \\
\hline L37 & 15.55 & Lungmachi & Black Shale & 2.83 & 2.01 & 2.5 & 0.51 & 0.72 & 0.037 & 0.093 & -30.3 & -5.2 \\
\hline L33 & 14.69 & Lungmachi & Black Shale & 2.58 & 2.39 & 2.7 & 0.53 & 0.77 & 0.015 & 0.093 & -30.6 & -3.8 \\
\hline L29 & 13.94 & Lungmachi & Black Shale & 2.85 & 2.12 & 2.6 & 0.49 & 0.77 & 0.016 & 0.090 & -30.6 & -1.4 \\
\hline L26 & 13.37 & Lungmachi & Black Shale & 2.54 & 1.99 & 2.8 & 0.47 & 0.71 & 0.036 & 0.087 & -30.5 & -2.7 \\
\hline L22 & 12.71 & Lungmachi & Black Shale & 2.66 & 1.93 & 2.5 & 0.51 & 0.70 & 0.037 & 0.106 & -30.6 & -1.1 \\
\hline L19 & 12.23 & Lungmachi & Black Shale & 4.91 & 1.57 & 2.1 & 0.50 & 0.69 & 0.018 & 0.121 & -30.7 & -3.3 \\
\hline L17 & 11.75 & Lungmachi & Black Shale & 2.05 & 2.37 & 2.7 & 0.57 & 0.72 & 0.021 & 0.122 & -30.6 & -4.5 \\
\hline L14 & 11.33 & Lungmachi & Black Shale & 2.98 & 2.37 & 2.5 & 0.58 & 0.76 & 0.014 & 0.121 & -30.5 & -4.6 \\
\hline L10 & 10.86 & Lungmachi & Black Shale & 3.1 & 2.07 & 2.6 & 0.48 & 0.78 & 0.017 & 0.079 & -30.5 & -11.5 \\
\hline L7 & 10.46 & Lungmachi & Black Shale & 2.48 & 2.51 & 2.6 & 0.59 & 0.77 & 0.019 & 0.106 & -30.5 & -3.3 \\
\hline L6 & 10.32 & Lungmachi & Black Shale & 3 & 2.49 & 2.6 & 0.55 & 0.81 & 0.007 & 0.086 & -30.2 & -3.2 \\
\hline L5 & 10.09 & Lungmachi & Black Shale & 3.44 & 2.75 & 2.6 & 0.60 & 0.81 & 0.015 & 0.090 & -30.2 & -3.4 \\
\hline $\mathrm{L} 4$ & 9.98 & Lungmachi & Black Shale & 5.57 & 2.46 & 2.4 & 0.59 & 0.80 & 0.014 & 0.097 & -30.0 & -7.9 \\
\hline L3 & 9.86 & Lungmachi & Black Shale & 3.37 & 2.47 & 2.5 & 0.62 & 0.73 & 0.051 & 0.105 & -29.8 & -1.1 \\
\hline L2 & 9.74 & Lungmachi & Black Shale & 5.18 & 2.53 & 2.5 & 0.62 & 0.78 & 0.021 & 0.104 & -29.6 & 0.6 \\
\hline L1-3 & 9.63 & Lungmachi & Black Shale & 3.21 & 2.66 & 2.7 & 0.57 & 0.81 & 0.014 & 0.087 & -29.6 & -0.1 \\
\hline L1-2 & 9.53 & Lungmachi & Black Shale & 2.6 & 2.47 & 2.5 & 0.58 & 0.79 & 0.016 & 0.097 & -29.6 & 0.1 \\
\hline $\mathrm{L} 1$ & 9.43 & Lungmachi & Black Shale & 2.81 & 3.07 & 2.7 & 0.65 & 0.81 & 0.009 & 0.108 & -29.5 & -3.1 \\
\hline G13 & 9.33 & Kuanyinchiao & $\begin{array}{l}\text { Argillaceous } \\
\text { Limestone }\end{array}$ & 0.476 & 0.80 & 1.0 & 0.86 & 0.44 & 0.114 & 0.412 & -29.1 & -6.5 \\
\hline G12 & 9.22 & Kuanyinchiao & $\begin{array}{c}\text { Argillaceous } \\
\text { Limestone }\end{array}$ & 0.379 & 2.61 & 1.7 & 0.90 & 0.79 & 0.013 & 0.169 & -29.5 & 8.3 \\
\hline G11 & 9.11 & Kuanyinchiao & $\begin{array}{l}\text { Argillaceous } \\
\text { Limestone }\end{array}$ & 0.379 & 2.21 & 1.7 & 0.84 & 0.73 & 0.040 & 0.178 & -29.2 & 8.8 \\
\hline G10 & 9.01 & Kuanyinchiao & $\begin{array}{l}\text { Argillaceous } \\
\text { Limestone }\end{array}$ & 0.733 & 1.70 & 1.8 & 0.71 & 0.62 & 0.012 & 0.253 & -28.9 & 3.1 \\
\hline G8-3 & 8.80 & Kuanyinchiao & $\begin{array}{l}\text { Argillaceous } \\
\text { Limestone }\end{array}$ & 0.806 & 1.33 & 1.5 & 0.89 & 0.46 & 0.020 & 0.458 & -29.0 & -1.0 \\
\hline G8-2 & 8.73 & Kuanyinchiao & $\begin{array}{l}\text { Argillaceous } \\
\text { Limestone }\end{array}$ & 0.753 & 1.14 & 1.6 & 0.78 & 0.43 & 0.039 & 0.406 & -29.0 & 5.2 \\
\hline G8 & 8.63 & Kuanyinchiao & $\begin{array}{l}\text { Argillaceous } \\
\text { Limestone }\end{array}$ & 0.664 & 1.15 & 1.5 & 0.84 & 0.42 & 0.015 & 0.469 & -29.3 & 3.3 \\
\hline G7 & 8.51 & Kuanyinchiao & $\begin{array}{l}\text { Argillaceous } \\
\text { Limestone }\end{array}$ & 1.16 & 1.14 & 1.5 & 0.85 & 0.41 & 0.023 & 0.475 & -29.3 & 1.0 \\
\hline G6 & 8.39 & Kuanyinchiao & $\begin{array}{l}\text { Argillaceous } \\
\text { Limestone }\end{array}$ & 0.839 & 1.67 & 1.5 & 0.82 & 0.62 & 0.041 & 0.272 & -29.0 & 2.1 \\
\hline
\end{tabular}




\begin{tabular}{|c|c|c|c|c|c|c|c|c|c|c|c|c|}
\hline G5 & 8.28 & Kuanyinchiao & $\begin{array}{l}\text { Argillaceous } \\
\text { Limestone }\end{array}$ & 0.871 & 1.64 & 1.6 & 0.75 & 0.63 & 0.040 & 0.237 & -28.9 & 0.8 \\
\hline G4 & 8.18 & Kuanyinchiao & $\begin{array}{l}\text { Argillaceous } \\
\text { Limestone }\end{array}$ & 0.854 & 1.79 & 1.6 & 0.82 & 0.64 & 0.029 & 0.261 & -28.8 & 1.6 \\
\hline G3-2 & 8.08 & Kuanyinchiao & $\begin{array}{l}\text { Argillaceous } \\
\text { Limestone }\end{array}$ & 0.713 & 1.46 & 1.4 & 0.81 & 0.60 & 0.022 & 0.296 & -29.1 & 8.4 \\
\hline G3-1 & 7.98 & Kuanyinchiao & $\begin{array}{l}\text { Argillaceous } \\
\text { Limestone }\end{array}$ & 2.4 & 1.66 & 1.4 & 0.82 & 0.67 & 0.017 & 0.250 & -28.8 & 11.6 \\
\hline G2 & 7.88 & Kuanyinchiao & $\begin{array}{l}\text { Argillaceous } \\
\text { Limestone }\end{array}$ & 0.7 & 1.83 & 1.5 & 0.82 & 0.70 & 0.012 & 0.235 & -28.5 & 12.7 \\
\hline W50 & 7.70 & Wufeng & Black Shale & 4.73 & 2.17 & 2.2 & 0.58 & 0.79 & 0.031 & 0.089 & -28.7 & 3.7 \\
\hline W49 & 7.63 & Wufeng & Black Shale & 2.9 & 3.21 & 2.3 & 0.78 & 0.83 & 0.015 & 0.108 & -28.5 & 6.9 \\
\hline W48 & 7.55 & Wufeng & Black Shale & 2.96 & 2.94 & 2.0 & 0.83 & 0.82 & 0.015 & 0.132 & -28.2 & 6.9 \\
\hline W47 & 7.48 & Wufeng & Black Shale & 3.48 & 5.32 & 2.7 & 1.05 & 0.90 & 0.006 & 0.100 & -28.2 & 13.6 \\
\hline W46 & 7.42 & Wufeng & Black Shale & 3.33 & 1.73 & 1.5 & 0.75 & 0.70 & 0.018 & 0.201 & -28.1 & 2.5 \\
\hline W45 & 7.36 & Wufeng & Black Shale & 4.03 & 3.56 & 2.5 & 0.81 & 0.81 & 0.023 & 0.126 & -28.0 & 10.5 \\
\hline W44 & 7.29 & Wufeng & Black Shale & 4.57 & 3.31 & 2.4 & 0.82 & 0.79 & 0.017 & 0.148 & -27.6 & 8.2 \\
\hline W43 & 7.21 & Wufeng & Black Shale & 4.68 & 3.60 & 2.4 & 0.89 & 0.81 & 0.017 & 0.149 & -28.2 & 9.0 \\
\hline W42 & 7.11 & Wufeng & Black Shale & 4.6 & 4.18 & 2.6 & 0.90 & 0.82 & 0.015 & 0.143 & -28.5 & 9.9 \\
\hline W41 & 6.98 & Wufeng & Black Shale & 5.01 & 3.85 & 2.9 & 0.81 & 0.76 & 0.040 & 0.149 & -28.3 & 7.9 \\
\hline W40 & 6.84 & Wufeng & Black Shale & 6.47 & 4.34 & 3.2 & 0.80 & 0.80 & 0.020 & 0.131 & -28.4 & 6.5 \\
\hline W39 & 6.70 & Wufeng & Black Shale & 7.4 & 5.37 & 3.3 & 0.88 & 0.87 & 0.007 & 0.105 & -28.7 & 1.4 \\
\hline W38 & 6.58 & Wufeng & Black Shale & 8.32 & 5.21 & 3.4 & 0.82 & 0.86 & 0.017 & 0.091 & -28.8 & 0.7 \\
\hline W37 & 6.47 & Wufeng & Black Shale & 6.89 & 4.08 & 3.2 & 0.70 & 0.86 & 0.010 & 0.085 & -29.4 & 1.8 \\
\hline W36 & 6.35 & Wufeng & Black Shale & 8.88 & 5.97 & 3.4 & 0.93 & 0.87 & 0.019 & 0.094 & -29.3 & 6.1 \\
\hline W34 & 6.14 & Wufeng & Black Shale & 6.25 & 3.42 & 2.4 & 0.80 & 0.82 & 0.018 & 0.120 & -29.9 & -4.8 \\
\hline W31 & 5.75 & Wufeng & Black Shale & 3.79 & 2.56 & 2.2 & 0.67 & 0.83 & 0.006 & 0.102 & -30.5 & -3.3 \\
\hline W28 & 5.42 & Wufeng & Black Shale & 4.33 & 1.81 & 1.7 & 0.64 & 0.77 & 0.011 & 0.123 & -30.3 & -11.9 \\
\hline W26 & 5.03 & Wufeng & Black Shale & 3.82 & 1.85 & 1.8 & 0.63 & 0.77 & 0.020 & 0.115 & -30.5 & -16.5 \\
\hline W25-10 & 4.55 & Wufeng & Black Shale & 3.44 & 1.56 & 2.2 & 0.45 & 0.74 & 0.019 & 0.107 & -30.6 & -19.6 \\
\hline W25-7 & 4.10 & Wufeng & Black Shale & 5.9 & 2.13 & 2.1 & 0.59 & 0.79 & 0.014 & 0.095 & -31.1 & -19.3 \\
\hline W25-3 & 3.62 & Wufeng & Black Shale & 3.11 & 1.94 & 1.9 & 0.72 & 0.68 & 0.042 & 0.149 & -30.7 & -14.0 \\
\hline W23 & 3.23 & Wufeng & Black Shale & 3.39 & 1.59 & 1.7 & 0.61 & 0.73 & 0.014 & 0.141 & -30.5 & -13.7 \\
\hline W19 & 2.61 & Wufeng & Black Shale & 3.01 & 1.42 & 1.5 & 0.64 & 0.68 & 0.016 & 0.174 & -30.3 & -17.4 \\
\hline W15 & 2.10 & Wufeng & Black Shale & 2.88 & 1.27 & 1.5 & 0.68 & 0.57 & 0.016 & 0.271 & -31.1 & -21.0 \\
\hline W12 & 1.77 & Wufeng & Black Shale & 2.73 & 1.05 & 1.3 & 0.63 & 0.62 & 0.019 & 0.207 & -30.2 & -21.8 \\
\hline W9 & 1.33 & Wufeng & Black Shale & 2.15 & 1.09 & 1.6 & 0.61 & 0.53 & 0.027 & 0.246 & -30.5 & -26.4 \\
\hline & & & & Shua & tes & ction & & & & & & \\
\hline AGH121 & 13.28 & Lungmachi & Black Shale & 5.28 & 0.83 & 0.7 & 0.88 & 0.65 & 0.059 & 0.253 & -30.40 & -1.67 \\
\hline AGH120 & 12.62 & Lungmachi & Black Shale & 4.67 & 0.83 & 0.8 & 0.85 & 0.58 & 0.105 & 0.252 & -30.23 & 8.49 \\
\hline AGH119 & 11.91 & Lungmachi & Black Shale & 5.4 & 0.92 & 1.0 & 0.83 & 0.53 & 0.113 & 0.279 & -30.19 & 14.49 \\
\hline AGH118 & 11.00 & Lungmachi & Black Shale & 7.73 & 1.38 & 1.2 & 0.83 & 0.67 & 0.062 & 0.207 & -30.24 & 6.75 \\
\hline
\end{tabular}




\begin{tabular}{|c|c|c|c|c|c|c|c|c|c|c|c|c|}
\hline AGH117 & 10.85 & Lungmachi & Black Shale & 9.73 & 1.07 & 1.0 & 0.73 & 0.72 & 0.006 & 0.202 & -29.55 & 5.85 \\
\hline AGH116 & 10.70 & Lungmachi & Black Shale & 7.72 & 1.42 & 1.4 & 0.74 & 0.63 & 0.038 & 0.227 & -29.55 & 12.36 \\
\hline AGH115 & 10.57 & Lungmachi & Black Shale & 8.1 & 1.05 & 1.2 & 0.65 & 0.65 & 0.013 & 0.214 & -29.64 & 5.73 \\
\hline AGH114 & 10.44 & Lungmachi & Black Shale & 6.08 & 1.07 & 0.9 & 0.90 & 0.61 & 0.021 & 0.331 & -29.61 & 17.49 \\
\hline AGH113 & 10.28 & Lungmachi & Black Shale & 2.74 & 0.42 & 0.6 & 0.77 & 0.46 & 0.077 & 0.339 & -29.61 & 9.20 \\
\hline AGH112 & 10.11 & Kuanyinchiao & $\begin{array}{l}\text { Argillaceous } \\
\text { Limestone }\end{array}$ & 1.16 & 2.57 & 1.8 & 0.96 & 0.67 & 0.103 & 0.197 & -29.13 & 11.49 \\
\hline AGH111 & 9.93 & Kuanyinchiao & $\begin{array}{l}\text { Argillaceous } \\
\text { Limestone }\end{array}$ & 2.82 & 3.58 & 2.2 & 0.91 & 0.83 & 0.016 & 0.134 & -29.29 & 13.70 \\
\hline AGH110 & 9.76 & Wufeng & $\begin{array}{l}\text { Dark grey } \\
\text { mudstone }\end{array}$ & 2.7 & 3.64 & 2.1 & 0.96 & 0.84 & 0.013 & 0.140 & -29.15 & 16.40 \\
\hline AGH108 & 9.52 & Wufeng & $\begin{array}{l}\text { Dark grey } \\
\text { mudstone }\end{array}$ & 4.61 & 2.17 & 1.9 & 0.75 & 0.70 & 0.038 & 0.178 & -29.29 & 14.81 \\
\hline AGH107 & 9.40 & Wufeng & $\begin{array}{l}\text { Dark grey } \\
\text { mudstone }\end{array}$ & 3.94 & 2.48 & 1.9 & 0.81 & 0.75 & 0.024 & 0.175 & -29.07 & 13.73 \\
\hline AGH106 & 9.28 & Wufeng & $\begin{array}{l}\text { Dark grey } \\
\text { mudstone }\end{array}$ & 4.21 & 2.56 & 1.9 & 0.84 & 0.76 & 0.025 & 0.169 & -29.01 & 12.07 \\
\hline AGH105 & 9.16 & Wufeng & $\begin{array}{l}\text { Dark grey } \\
\text { mudstone }\end{array}$ & 3.91 & 2.31 & 1.7 & 0.83 & 0.76 & 0.015 & 0.177 & -29.31 & 11.07 \\
\hline AGH104 & 9.01 & Wufeng & $\begin{array}{l}\text { Dark grey } \\
\text { mudstone }\end{array}$ & 4.21 & 2.84 & 2.0 & 0.85 & 0.76 & 0.023 & 0.173 & -29.33 & 10.00 \\
\hline AGH103 & 8.87 & Wufeng & $\begin{array}{l}\text { Dark grey } \\
\text { mudstone }\end{array}$ & 4.51 & 2.68 & 1.9 & 0.84 & 0.80 & 0.018 & 0.146 & -29.35 & 12.79 \\
\hline AGH102 & 8.72 & Wufeng & $\begin{array}{l}\text { Dark grey } \\
\text { mudstone }\end{array}$ & 4.42 & 2.78 & 2.0 & 0.78 & 0.82 & 0.015 & 0.120 & -29.36 & 17.67 \\
\hline AGH101 & 8.55 & Wufeng & $\begin{array}{l}\text { Dark grey } \\
\text { mudstone }\end{array}$ & 4.7 & 2.73 & 1.9 & 0.82 & 0.83 & 0.010 & 0.126 & -29.35 & 17.32 \\
\hline AGH99 & 8.21 & Wufeng & $\begin{array}{l}\text { Dark grey } \\
\text { mudstone }\end{array}$ & 5.16 & 2.00 & 1.7 & 0.78 & 0.69 & 0.060 & 0.178 & -29.58 & 11.44 \\
\hline AGH97 & 8.02 & Wufeng & Black Shale & 4.83 & 1.58 & 1.4 & 0.73 & 0.70 & 0.040 & 0.177 & -29.67 & 7.80 \\
\hline AGH96d & 7.89 & Wufeng & Black Shale & 4.51 & 2.35 & 1.8 & 0.89 & 0.69 & 0.028 & 0.249 & -29.59 & 6.88 \\
\hline AGH96c & 7.77 & Wufeng & Black Shale & 4.26 & 1.56 & 1.3 & 0.88 & 0.64 & 0.027 & 0.294 & -29.58 & 5.92 \\
\hline AGH96b & 7.65 & Wufeng & Black Shale & 4.83 & 1.40 & 1.2 & 0.94 & 0.57 & 0.029 & 0.373 & -29.38 & 10.33 \\
\hline AGH96a & 7.53 & Wufeng & Black Shale & 4.74 & 2.25 & 1.8 & 0.97 & 0.61 & 0.087 & 0.282 & -29.63 & 11.28 \\
\hline AGH95d & 7.39 & Wufeng & Black Shale & 6.36 & 4.47 & 2.9 & 0.95 & 0.77 & 0.049 & 0.163 & -29.84 & 9.10 \\
\hline AGH95c & 7.24 & Wufeng & Black Shale & 5.21 & 3.45 & 2.3 & 0.94 & 0.76 & 0.024 & 0.204 & -29.82 & 9.75 \\
\hline AGH95b & 7.10 & Wufeng & Black Shale & 4.94 & 5.27 & 3.0 & 1.00 & 0.79 & 0.085 & 0.120 & -29.95 & 12.95 \\
\hline AGH95a & 6.94 & Wufeng & Black Shale & 4.3 & 1.39 & 1.1 & 0.87 & 0.66 & 0.041 & 0.257 & -30.13 & 7.10 \\
\hline AGH95 & 6.80 & Wufeng & Black Shale & 3.79 & 0.93 & 0.9 & 0.88 & 0.56 & 0.116 & 0.273 & -30.21 & -0.23 \\
\hline AGH94c & 6.67 & Wufeng & Black Shale & 3.88 & 0.90 & 0.9 & 0.89 & 0.56 & 0.112 & 0.271 & -30.14 & 8.00 \\
\hline AGH94b & 6.47 & Wufeng & Black Shale & 3.13 & 1.35 & 1.2 & 0.85 & 0.61 & 0.068 & 0.259 & -30.35 & 6.39 \\
\hline AGH94a & 6.28 & Wufeng & Black Shale & 4.21 & 0.97 & 0.9 & 0.83 & 0.62 & 0.057 & 0.255 & -30.29 & 3.53 \\
\hline \multirow[t]{2}{*}{ AGH94 } & 6.17 & Wufeng & Black Shale & 2.88 & 0.61 & 0.7 & 0.77 & 0.50 & 0.080 & 0.307 & -30.32 & 11.69 \\
\hline & & & & & 43 & & & & & & & \\
\hline
\end{tabular}




\begin{tabular}{lllllllllllll} 
AGH93 & 5.31 & Wufeng & Black Shale & 3.48 & 0.99 & 1.0 & 0.72 & 0.64 & 0.023 & 0.236 & -30.80 & -6.55 \\
AGH92 & 4.97 & Wufeng & Black Shale & 2.84 & 0.91 & 0.8 & 0.83 & 0.63 & 0.019 & 0.291 & -30.64 & -3.24 \\
AGH91 & 4.42 & Wufeng & Black Shale & 2.58 & 1.21 & 1.2 & 0.84 & 0.57 & 0.061 & 0.300 & -30.54 & 7.76 \\
AGH90 & 3.96 & Wufeng & Black Shale & 3.09 & 0.77 & 0.9 & 0.78 & 0.49 & 0.051 & 0.347 & -30.43 & -9.50 \\
AGH89 & 3.36 & Wufeng & Black Shale & 3.06 & 1.62 & 1.5 & 0.76 & 0.66 & 0.029 & 0.226 & -30.39 & 3.01 \\
AGH88 & 3.11 & Wufeng & Black Shale & 3.73 & 1.30 & 1.3 & 0.76 & 0.62 & 0.049 & 0.241 & -30.46 & -6.13 \\
AGH87 & 2.76 & Wufeng & Black Shale & 3.43 & 0.73 & 0.9 & 0.69 & 0.53 & 0.021 & 0.303 & -30.36 & -16.83 \\
AGH86 & 1.88 & Wufeng & Black Shale & 3.18 & 1.28 & 2.0 & 0.70 & 0.43 & 0.038 & 0.356 & -30.49 & -7.24 \\
\hline
\end{tabular}




\section{Datianba Section}

- $\mathrm{TOC}(w t \%)$

- $\mathrm{Fe}_{\mathrm{HR}} / \mathrm{Fe}_{\mathrm{T}}$

- $\mathrm{Fe}_{\text {carb }} / \mathrm{Fe}_{\mathrm{T}}$

- $\delta^{13} \mathrm{C}_{\text {org }}(\%)$

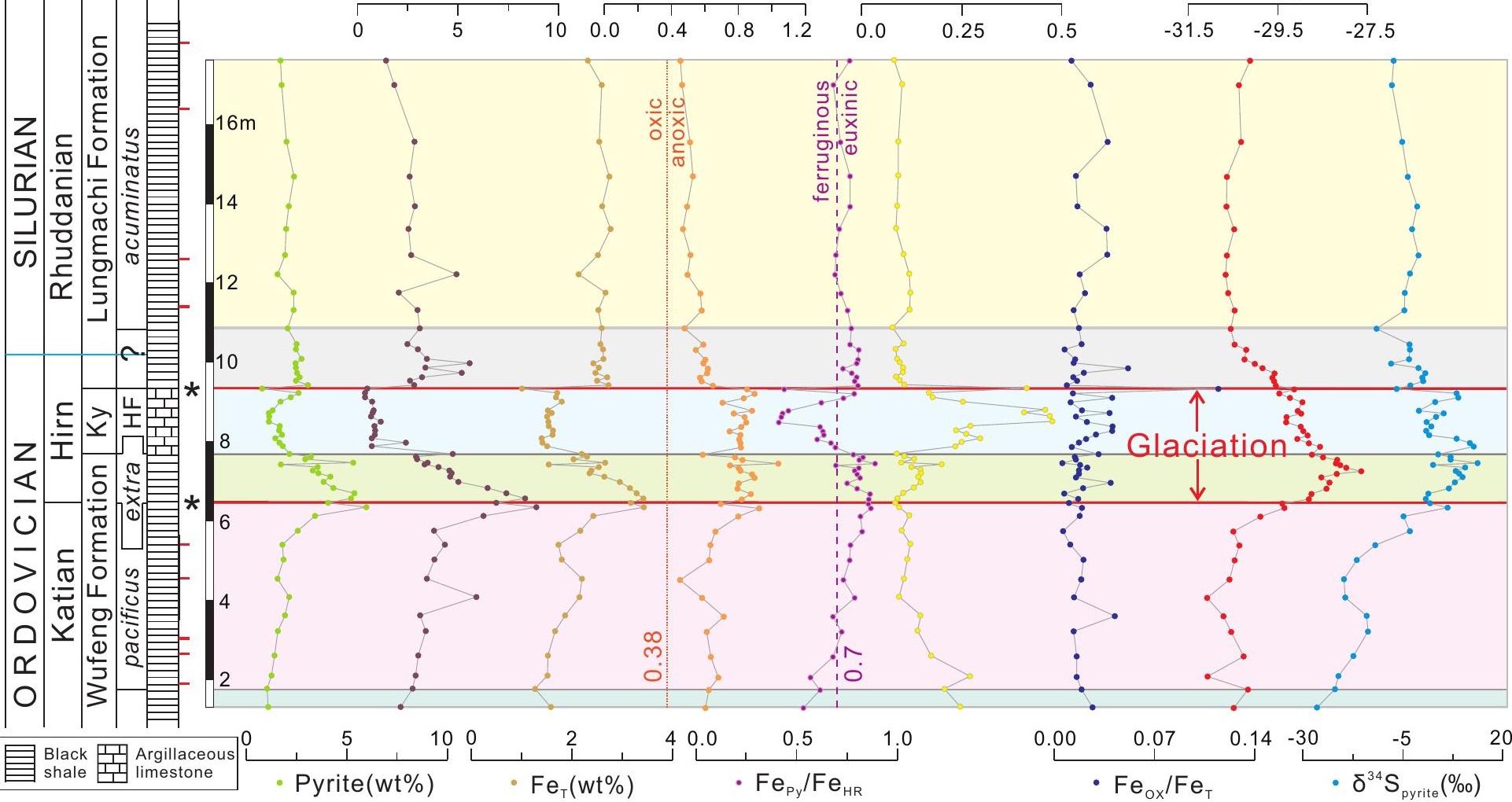




\section{Shuanghe Section}

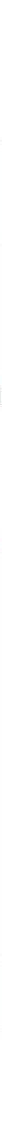




\section{Wangjiawan Sections}

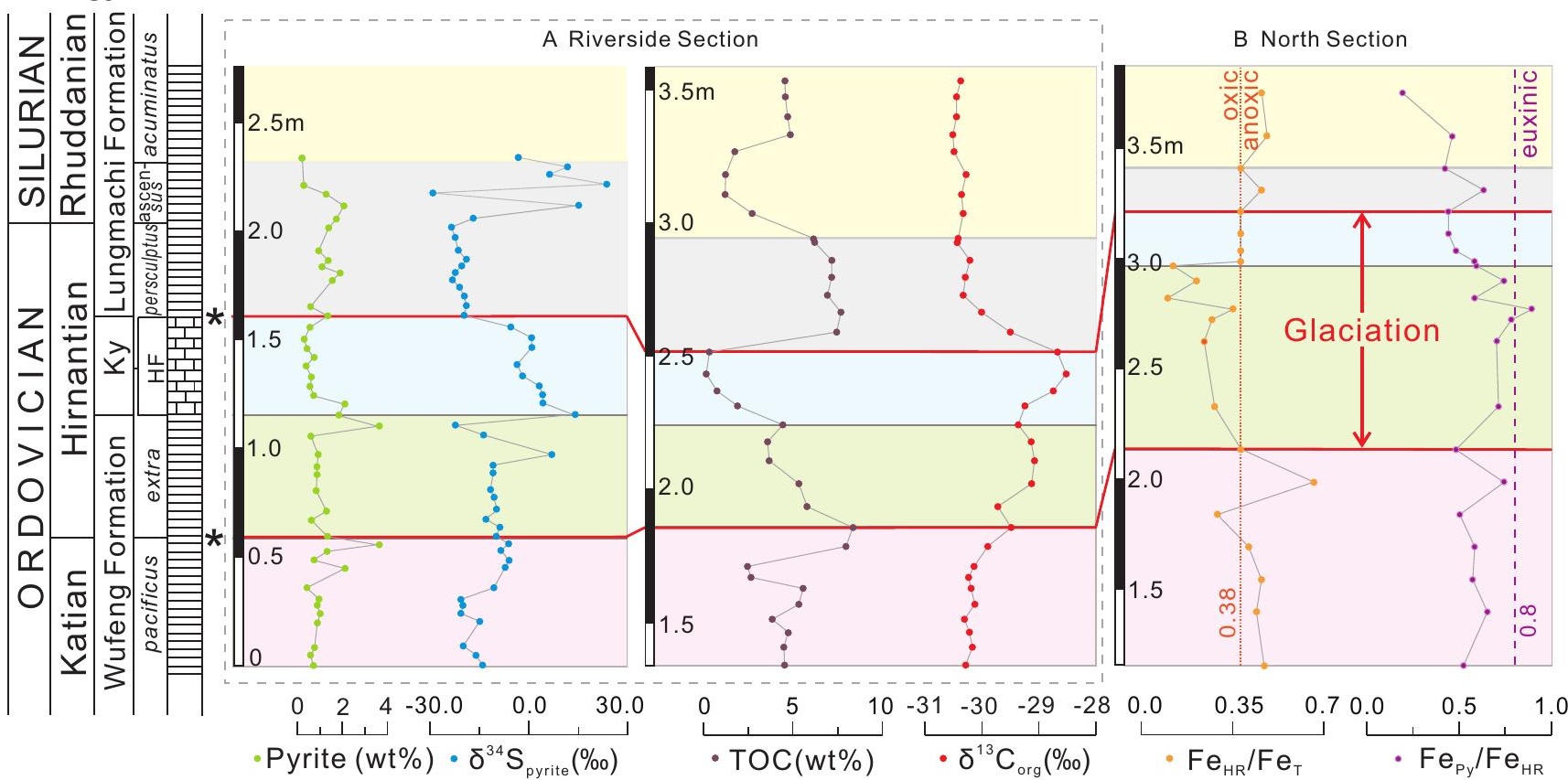


